Chapter 4

\title{
Global Distribution of the Dominant Vector Species of Malaria
}

\author{
Marianne E. Sinka \\ Additional information is available at the end of the chapter \\ http://dx.doi.org/10.5772/54163
}

\section{Introduction}

Human malarial protozoa are transmitted by mosquitoes of the genus Anopheles. There are 465 formally recognised species and more than 50 unnamed members of species complexes [1]. Approximately 70 of these species have the capacity to transmit human malaria parasites [2] and 41 are considered here to be dominant vector species/species complexes (DVS), capable of transmitting malaria at a level of major concern to public health [3, 4] (Tables 1-3).

The aim of this chapter is to document the distribution of these DVS using global and regional maps. In addition, behavioural summaries are provided for the most important species, i.e. those on each continent that are considered the most dangerous and responsible for most malaria transmission, and hence have the greatest impact on human health. Only the primary vectors in those regions with current and problematic malaria transmission are discussed further here (i.e. the vectors of Europe and the Middle-East are not included - but more details can be found in Sinka et al. [5]) The regions covered include the Americas, Africa and the Asian-Pacific.

The maps presented (e.g. Figure 1) provide species location information and highlight the existence of a greater number of vector species than is often considered, many in sympatry, across the malarial zones. Amongst these DVS, there are often important behavioural characteristics that must be considered if successful vector control is to be applied. For example, some species do not always enter houses to bite, are most active in the early evening, and prefer to rest outdoors after feeding, such as many of the species common in South America (e.g. An. albopictus, An. marajoara, An. nuneztovari), An. dirus in South-East Asia and An. farauti in the Australian-Pacific region. Others are highly opportunistic in their feeding habits (including An. darlingi, the most 'dominant' south American species amongst the South American DVS); biting readily indoors or out. As such, a large investment in insecticide treated bednets (ITNs) or insecticide residual spraying (IRS) will not reduce malaria transmission where such species 
occur. Thus, to appreciate where different malaria control methods are best applied, one must know what Anopheles species exists in an area and understand their behaviour. A map clearly and simply addresses the first of these needs, and if accompanied by a behavioural summary, than informed decisions about how to combat malaria transmission can be made.

Maps clearly illustrate the spatial extent of a species' distribution. Often, even within a single Anopheles species range, behaviour can vary depending on location. The best known example is the An. gambiae complex. The An. gambiae complex was initially considered as a single species. Clear differences in behaviour reported across its distribution caused it to be examined more closely and now this complex is considered to include eight species [1, 6] including the DVS: An. arabiensis, An. gambiae, An melas and An. merus. Anopheles arabiensis, is considered mostly zoophilic, when compared to the highly anthropophilic An. gambiae, but still plays a very important role in malaria transmission - indeed, its presence and propensity to rest outdoors is attributed (amongst other factors) to the 'failure' of the mass indoor residual spraying program intended to control malaria in Nigeria during the Garki project [7]. Variability in behaviour within the An. gambiae species (rather than the complex) is also commonly reported [5]. Such spatially dependant variability amongst the DVS will be discussed further within this chapter.

The maps presented in this chapter are not a comprehensive analysis of all anophelines. They show only those species designated as DVS; a categorisation initially based on information taken from a number of authoritative reviews [8-12] ([10] translated and updated:[13]) and with additional guidance from a technical advisory group of vector experts $[3,5,14,15]$. This chapter will also briefly touch upon the methodology behind creating the distribution maps for these DVS including what information is needed to ensure increasingly accurate maps can be produced in future.

\section{Global}

The global DVS map (Figure 1) gives a clear overview of the variability in vector complexity across the world. Africa appears to show a relatively simple picture of a small number of highly dominant species covering large areas of the continent and although the 'secondary DVS' are not shown (see Figure 4), even with their influence, the comparative complexity between African and Asia is very different. The Asian-Pacific region has 19 DVS [14] (16 of which are shown on the multi-species maps presented here (Figures 1 \& 5) - see below) whereas Africa has only seven DVS [5], with the three 'primary' DVS shown on the global map (Figure 1 - see below). Of the 19 species in the Asian-Pacific, nine are now considered species complexes, whereas of the seven African DVS, only An. nili is a confirmed species complex (the An. gambiae complex is not included here, as specific individual members of the complex are categorised within these seven African DVS) $[1,6,16]$. It is unclear what is the cause of the high diversity of vectors found in the Asian-Pacific region, but it may be simply a factor of the large number of islands, and hence a consequence of limitations in dispersal and specialisation within a restricted environment. Whatever the reason, the Asian-Pacific region maintains a high number of vectors and species complexes and even within individual species, behaviours can vary hugely depending on location (e.g. An. annularis - see below). 
North America (excluding Mexico) shows a simple vector profile (Figure 2). There are only two species considered here as DVS: An. freeborni found in northwestern USA and the An. quadrimaculatus complex, found in the southern regions of the country. In Latin America, however, the situation is a little more complex. Despite a number of sympatric species on the continent, An. darlingi is considered the most important vector in the neotropical region [13] and hence is shown dominating all localities where it occurs. In Central America this species does not have such a great influence and both An. albimanus and An. pseudopunctipennis are considered of greater importance.

The individual regions (Americas, Africa, and Asia-Pacific) are discussed in more detail in the following sections.

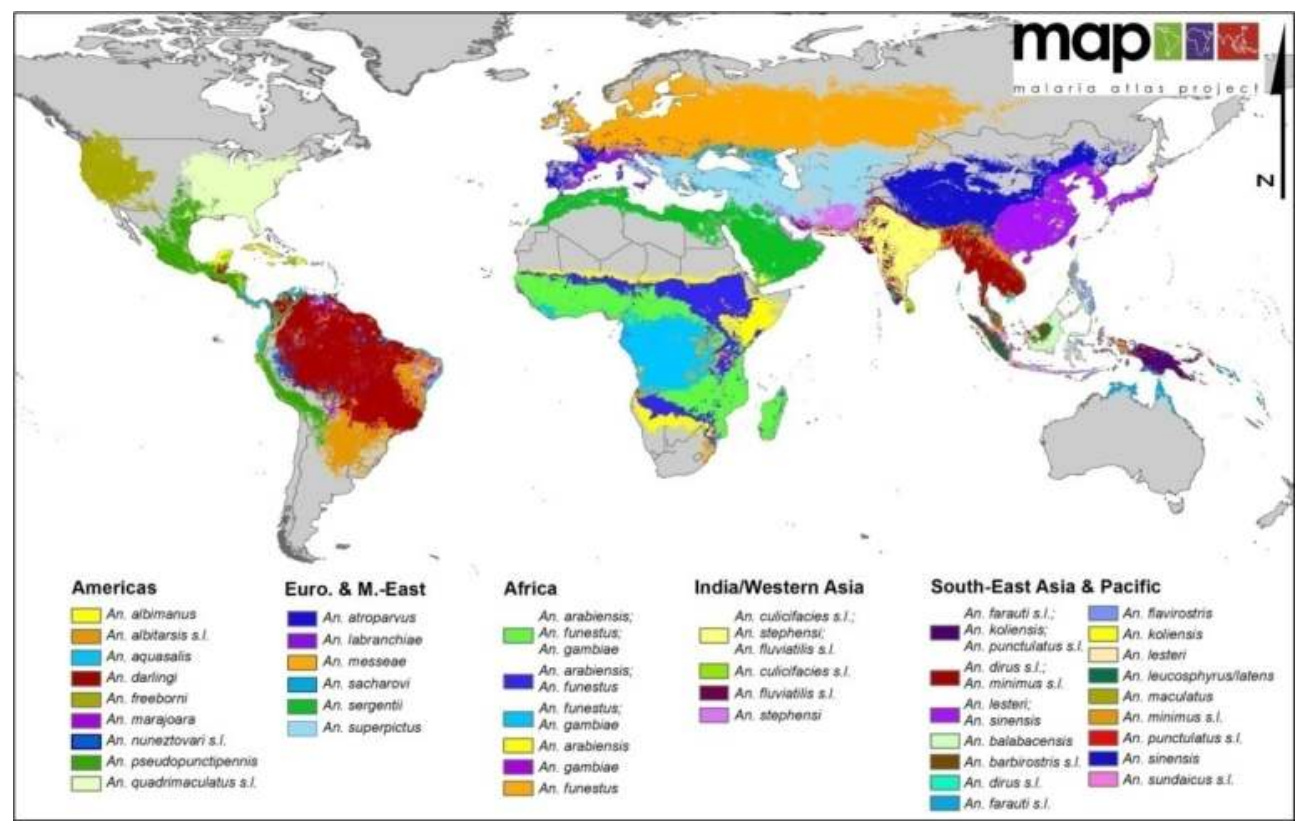

Figure 1. The global distribution of 34 DVS. (Map reproduced from Sinka et al. [4]); s.l.: sensu lato, meaning 'in the broad sense' referring to species complex

\section{The Americas}

On a global scale, the nations of the Americas benefit from having the lowest $P$. falciparum morbidity, with stable risk areas typically having low levels of endemicity $\left(\operatorname{PfPR}_{2-10} \leq 5 \%\right)$ [17]. Such reduced levels of malaria transmission coupled with continuing reports of decreasing mortality and morbidity for all major Plasmodium species across the region (e.g. between 2000 and 2007) [18] have been credited to an increasing use of integrated vector control [19]. 
Integrated vector control/management relies on a number of factors, but foremost (as given in the World Health Organisation (WHO), strategic framework for integrated vector management [20]) is the 'selection of proven vector control methods based on knowledge of local vector biology and ecology, disease transmission and morbidity'; essentially, knowing which vector species is present and understanding how it behaves.

There are nine DVS in the Americas (Figure 2, Table 1) [15], with two species having their distributions contained entirely within North America (An. freeborni and An.quadrimaculatus), and the remaining six species encompassing areas from southern North America, through Central America and into South America, incorporating the northern reaches of Argentina. As stated above, in South America, An. darlingi is considered to be the most important of the DVS where it is found [13]. However there is increasing evidence of the importance of other species, including members of the An. albitarsis complex (e.g. An. marajoara), that may have a higher influence in malaria transmission than previously thought [21]. As such, and due to the dominance across the continent indicated by the An. darlingi distribution in Figure 2, single species maps are also shown for An. albitarsis, An. marajoara, An. nuneztovari and An. pseudopunctipennis (Figure 3).

Many of the American species show great variability in their adult behaviour, with most showing little preference for biting either humans or animals [15] (Table 1), tending to feed on whichever host they first encounter. This variability is also reflected in their propensity to bite both indoors and out. Overall, the majority of DVS in the Americas will rest outside after biting (Table 1, [15]).

Despite similar adult behaviour amongst many of the South American DVS, there are a number of behavioural characteristics found in the larval stages that do differentiate the species (Table 1). For example An. aquasalis, whose name means salt (salis) water (aqua), is a vector found in coastal environments. Its larvae prefer clear, non-polluted water bodies such as mangrove swamps, lagoons and ditches [22, 23]. They can develop in fresh water sites, but it is considered a poor competitor in such habitats, especially against An. albimanus [15], which may be causal in tending to restrict the range of $A n$. aquasalis to brackish locations.

Anopheles darlingi larvae are characteristically associated with patches of floating debris found along river margins in rural and lowland forested areas [24]. Anopheles marajoara is also found in lowland areas but is more common in secondary forests and is able to adapt to environments that have undergone some human intervention [21, 25] which may be a causal factor in its increasing dominance over An. darlingi in some localities. Forest clearance and pollution will decrease sites suitable for $A n$. darlingi but increase the availability of sunlit marshy areas and ponds more suitable for An. marajoara [21, 26].

The An. pseudopunctipennis complex is known to be able to survive and transmit malaria at altitudes higher than many other DVS, up to $3000 \mathrm{~m}$ [27, 28]. Its larvae also have a defining characteristic; an apparent obligate association with filamentous Spirogyra-type green algae $[23,27,29-31]$ (Table 1). Indeed, the removal of such algae has been shown to be a viable method of control for this species [31]. 


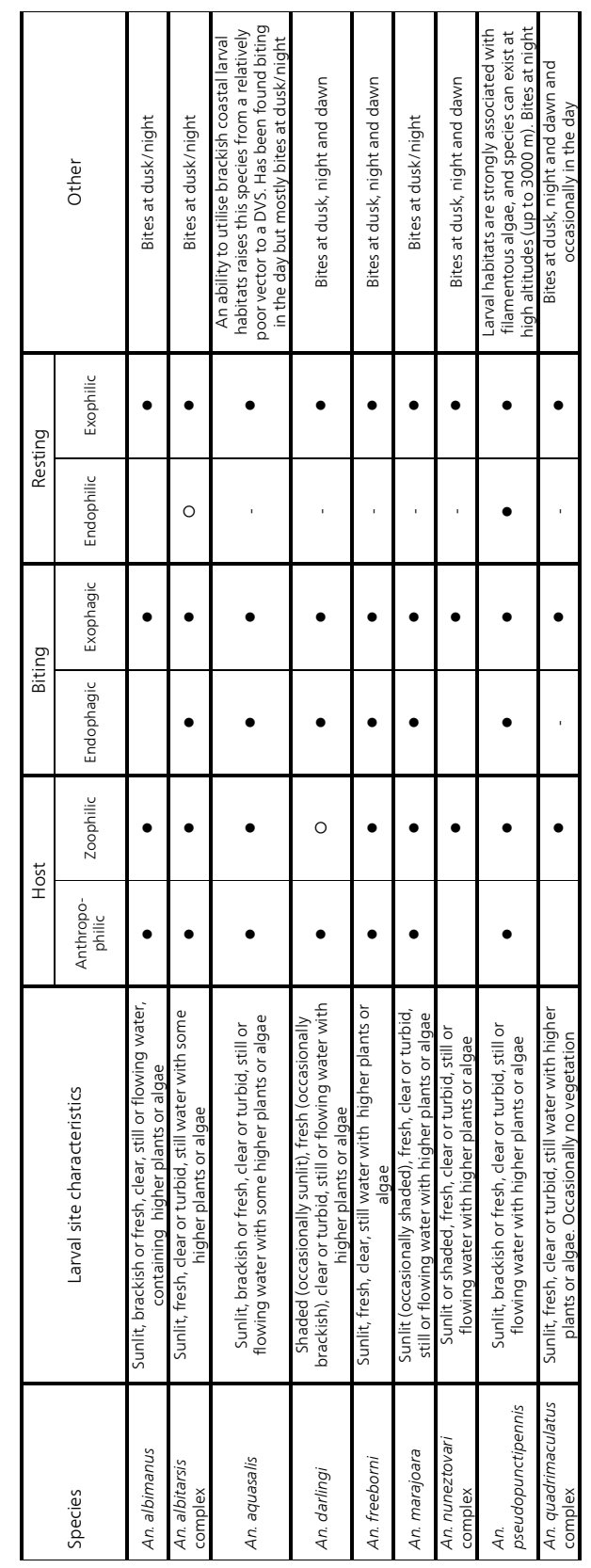

Table 1. Summary of bionomics of the DVS of the Americas (created by cross referencing TAG and literature searches). Filled dot $(\bullet)$ indicates typical behaviour, open dot (o) indicates non-typical behaviour but examples exist, and dashes (-) indicate no data. 


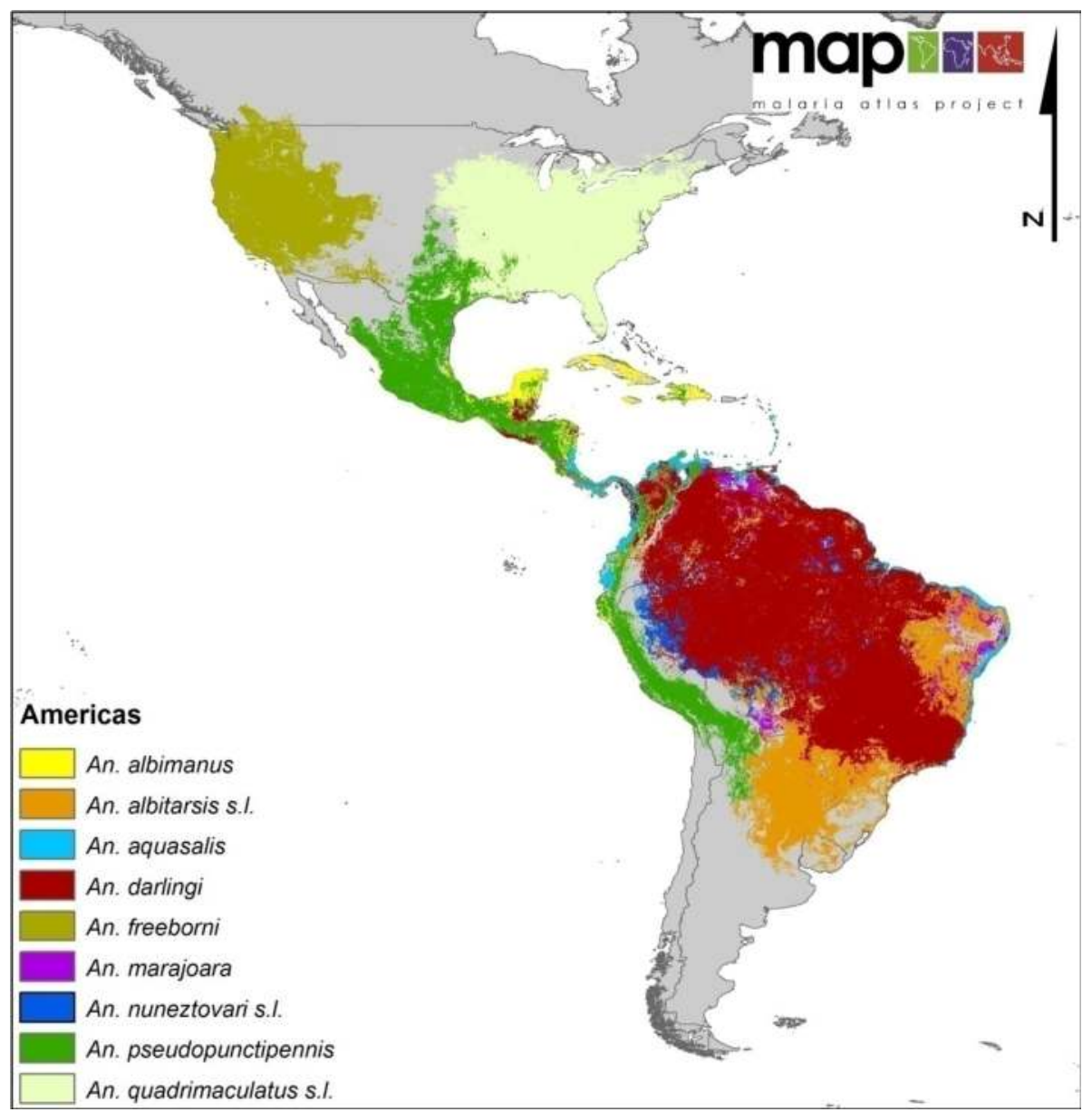

Figure 2. Multi-species map of the nine DVS of the Americas (map reproduced from Sinka et al. [4])

\section{Africa}

Across the huge and variable landscape of the African continent, there is a corresponding variability in the intensity of malaria transmission [32,33]. Sub-saharan Africa is, however, home to localities suffering from the highest global malaria transmission levels, and hence, morbidity and mortality of malaria [17, 32, 34-36]; a consequence of the wide spread presence of the most effective and efficient vector currently known, An. gambiae [37, 38]. Anopheles gambiae is a member of the An. gambiae complex, which also contains other DVS including An. arabiensis, An. merus and An. melas [6, 39-42]. Also found in Africa is the widespread An. 


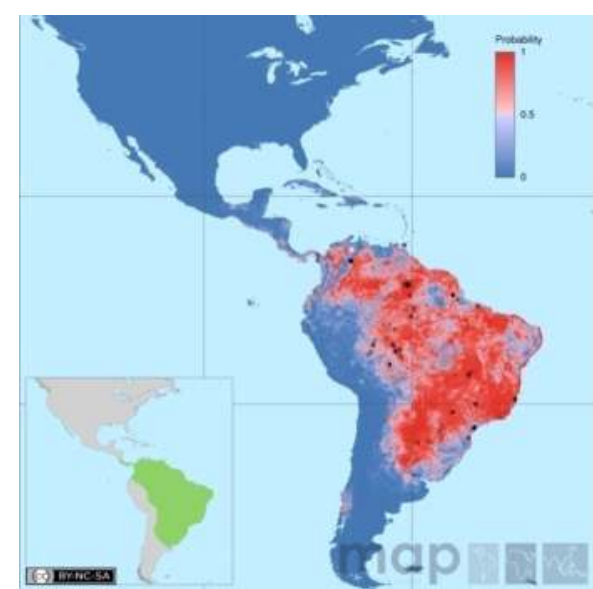

(a)

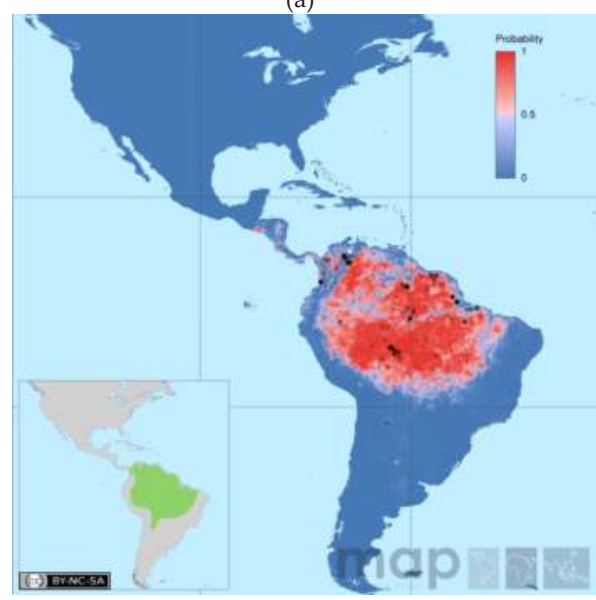

(c)

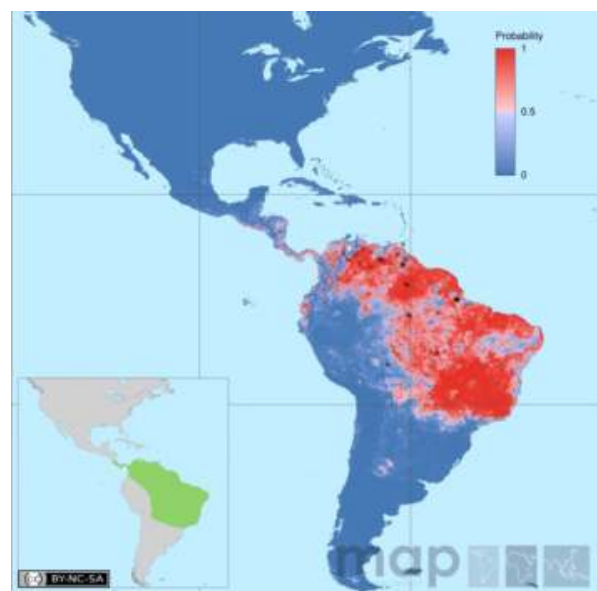

(b)

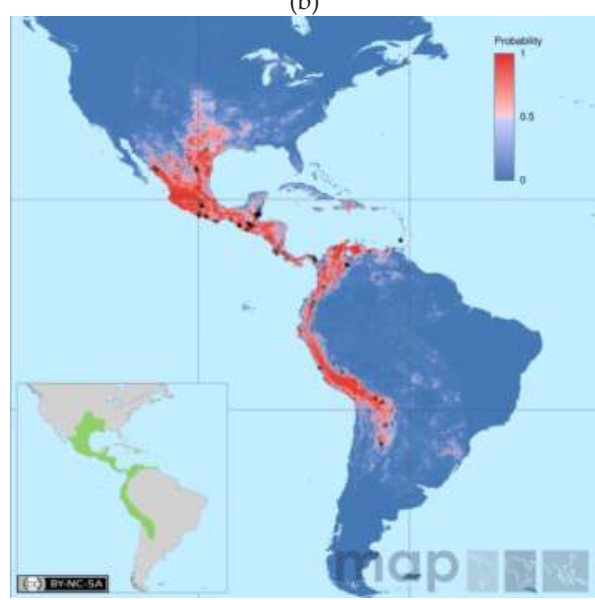

(d)

Figure 3. Predicted distribution maps for a) An. albitarsis s.I. $(n=138) ; b)$ An. marajoara $(n=56) ; c)$ An. nuneztovari $(n=$ 171); d) An. pseudopunctipennis ( $n=156)$. The insert map in each shows the expert opinion distribution for that species (Maps reproduced from Sinka et al, [15]).

funestus subgroup of which An. funestus is another highly effective vector, and possibly the first species to adapt to make use of humans as a food/blood source [43]. The more restricted, but still highly anthropophilic An. moucheti and the more widespread An. nili complex add to a suite of vectors within Africa that have proved highly efficient in malaria transmission and equally difficult to control [5].

Figure 1 shows those vector species that can be considered the 'primary' DVS of Africa: An. gambiae, An. arabiensis and An. funestus. Figure 4 indicates the more 'secondary' DVS, including An. moucheti, An. nili, An. melas and An. merus. Examining only the 'primary' species (Figure 1 ), the vector situation in Africa appears relatively simple. However for each of these species 
to have an extensive spread across such a large geographical area suggests a high level of adaptability and plasticity in behaviours and tolerances within all of these DVS. This plasticity is becoming more apparent as the taxonomy of the species complexes are untangled. The $A n$. gambiae complex is a case in point. Originally considered as one species, the discovery of saline tolerant larval 'An. gambiae' coastal specimens which, in cross mating experiments, produced sterile male progeny, confirmed that the salt-water tolerant and fresh-water 'An. gambiae' were reproductively incompatible, and identified An. melas on the west coast and An. merus on the east [44-47]. The Gambiae complex is now known to consist of at least eight species [1,6] yet this taxonomic categorisation is still a relatively recent occurrence, with the provisional inclusion of An. quadriannulatus B only reported in 1998 [6, 48]. Moreover, behavioural and ecological plasticity within the An. gambiae species itself have highlighted further potential speciation; there are now five recognised chromosomal forms (Savanna, Mopti, Forest, Bamako and Bissau) and two molecular forms ( $\mathrm{M}$ and S) [49-51]. The $\mathrm{M}$ and $\mathrm{S}$ forms have distinctive and separate behaviours, specifically in terms of preferred larval habitats, with the $S$ form utilising larval sites considered typical for An. gambiae (i.e. temporary pools or puddles that only occur after rain) whereas larvae from the $\mathrm{M}$ form are found in more permanent sites such as rice fields or flooded areas [52-57]. Overall, An. gambiae is considered highly anthropophilic (Table 2), a characteristic that is held as greatly influential in the designation of this species as the most effective malaria vector. It also tends to be reported as biting indoors and during the night when people are asleep and therefore more vulnerable [5]. Although these traits do tend to hold true in a general sense, the variability of An. gambiae does extend to adult behaviour and there are a number of localities where this species does not follow these commonly reported behaviours [5].

The extensive distribution of An. arabiensis (Figure 1) also indicates a vector with a wide range of behaviours $[40,58,59]$ and although it is classified as zoophilic and exophagic (Table 2) this is often only reported in comparison with the generally highly anthropophilic and endophagic An. gambiae or An. funestus [5, 60]. Anopheles arabiensis is more tolerant of drier environments than the other DVS, as can be seen in Figure 1 where its range extends north (the Sahel) and south (desert and steppe of Namibia and Botswana) beyond those of either An. gambiae or An. funestus. It is noticeably absent from the humid, forested areas of western Africa (Figure 1).

Despite the zoophilic label, the feeding behaviour of An. arabiensis varies greatly depending upon location, host availability and the local genotype [40, 58, 59, 61] and there is some suggestion that $A n$. arabiensis populations are more anthropophilic, endophilic and endophagic in western Africa whereas those in the east are more zoophilic and exophilic [62].

Beside the apparent inability to exist in the forested west of Africa, An. arabiensis appears to tolerate a much greater range of larval sites than An. gambiae. Similar to its sibling, it makes use of sunlit, temporary, shallow fresh-water habitats and the larger more permanent sites as characterised by An. gambiae M form, but it is also able to survive in flowing water, turbid or polluted sites and even, on occasion, brackish habitats [5, 63-66]. It readily makes use of rice fields, although its propensity for sunlit water means it is primarily found when the rice plants are small and larval numbers reduce substantially as the plants mature [67-70]. The adapta- 


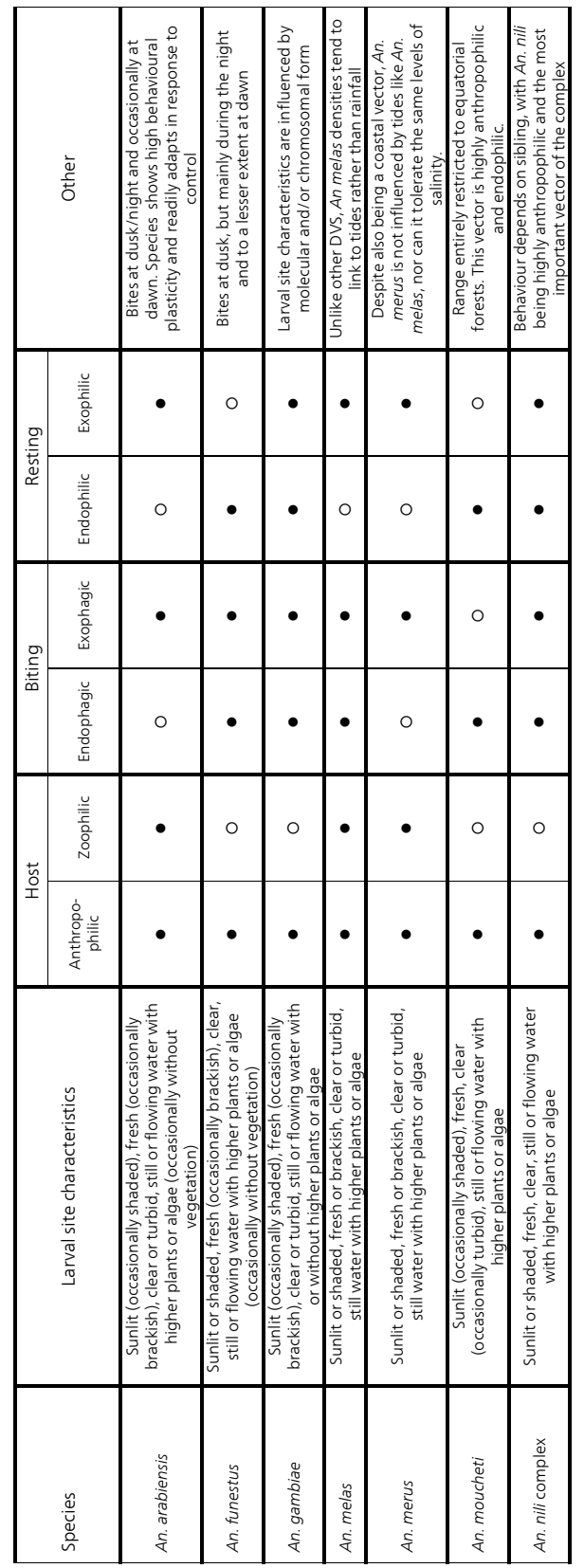

Table 2. Summary of bionomics of the DVS of Africa (created by cross referencing TAG and literature searches) Filled $\operatorname{dot}(\bullet)$ indicates typical behaviour, open $\operatorname{dot}(\circ)$ indicates non-typical behaviour but examples exist, and dashes (-) indicate no data. 
bility, plasticity and general tendencies for An. arabiensis to feed outdoors on animals (Table 2) means that this species does not readily succumb to traditional methods of control such as IRS or ITNs [59, 71, 72].

Anopheles funestus, is a highly adaptable species with a large distribution across sub-saharan Africa (Figure 1). It is also a highly effective vector, and in some cases, due to a relatively high longevity plus a preference for human blood and late night biting (Table 2), is even more efficient at transmitting malaria than An. gambiae [38, 40, 73]. Anopheles funestus is the only member within the Funestus Subgroup regarded as an important vector [73], and can only be morphologically distinguished from other members at certain stages in their development, again highlighting the importance of correct species identification [38, 40, 73, 74]. Indeed, for this subgroup, such identification is rarely reported, and hence the distributions illustrated here (Figure 1) cannot distinguish the true range of this specific vector. For example in Ethiopia, only one known study has performed PCR identifications of the Funestus Group [75], indicating that only An. parensis (a non-vector member of the Funestus Subgroup) is present.

Anopheles funestus is a highly anthropophilic mosquito [5, 38, 76, 77] and its endophilic behaviour adds to a suite of behaviours that enhance its ability to effectively transmit malaria [5]. It is comparably consistent in its behaviour and has been subject to successful control via both IRS and ITNs, but some populations have shown a rapid development of insecticide resistance to pyrethroids which was considered the primary cause of epidemic malaria reported in South Africa in the late 1990s [73, 78].

The larvae of An. funestus are found in large permanent or semi-permanent bodies of freshwater such as swamps, large ponds or lake edges [5]. They are also associated with rice cultivation in some localities, favouring older fields with mature rice plants [79-81].

\section{Asia}

The region of Central, South and East Asia is home to $46 \%$ of the global populations at risk (PAR) of stable falciparum malaria [82] and suffers a particularly high impact of vivax malaria, with an estimated $82 \%$ of the world's PAR of $P$. vivax transmission [83]. Indeed within the 'top $10^{\prime}$ of countries with the highest global $P$. vivax PAR estimates, seven are from Asia (China, Indonesia, Pakistan, Vietnam, the Philippines, Myanmar and Thailand) [84]. The complexity of the vector situation in the Asian-Pacific region increases the problems associated with understanding the vector/transmission environment. This region has a greater number of DVS than any other and amongst these, there are a greater number of species complexes and taxonomic complexities than anywhere else $[1,6,16]$.

With at least nine out of 19 DVS found in the Asian-Pacific now considered as a species complex $[1,6]$, the impetus to correctly identify both the vectors and their behaviours at a specific location is even greater in this region than elsewhere. Indeed, even within those species not currently considered as part of a complex, behavioural variability is common, depending upon location, and in some cases to such an extent that a species considered a vector in one location 


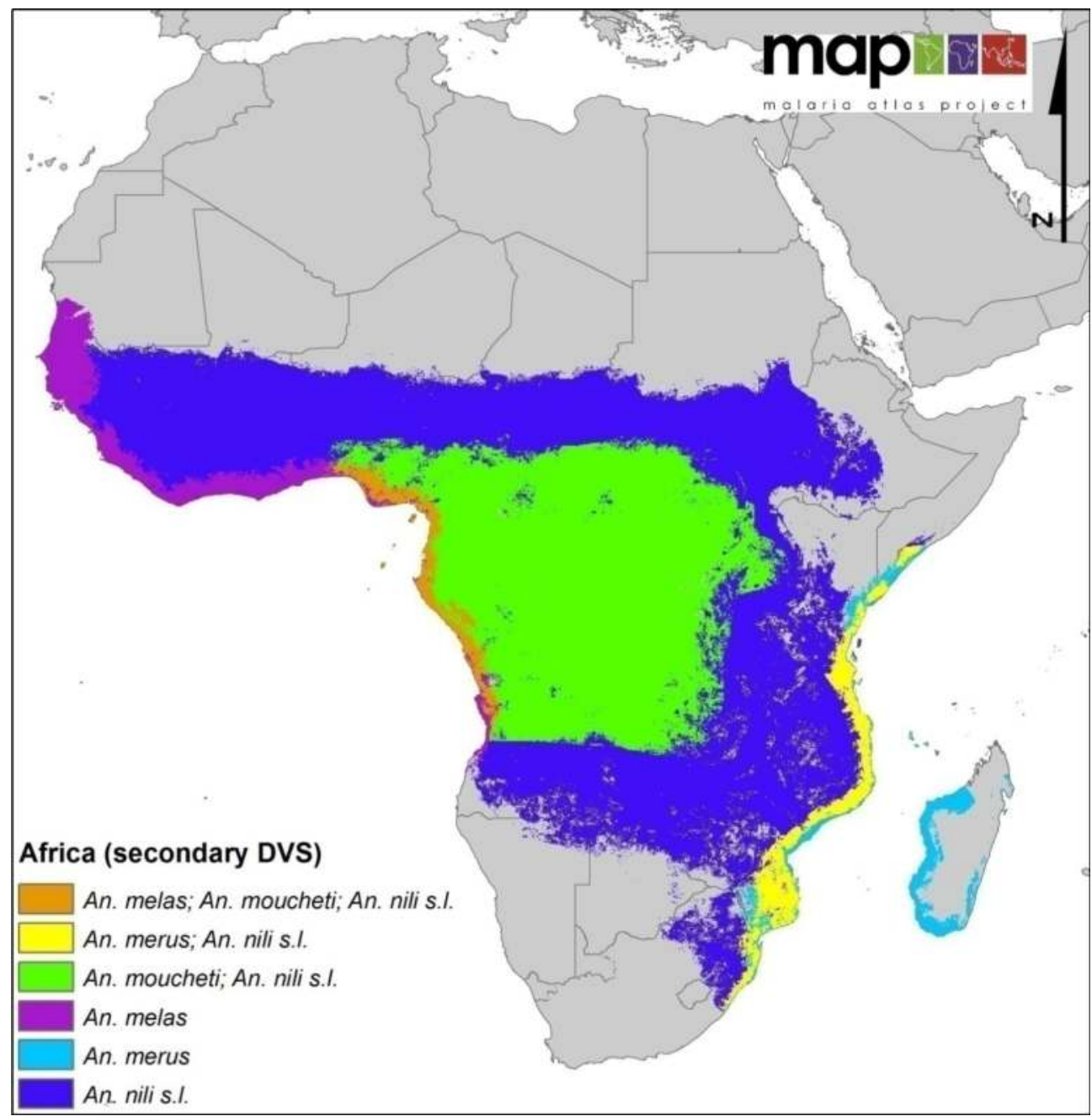

Figure 4. Multi-species map of Africa indicating the distributions of the four 'secondary' but still important, DVS. (map reproduced from Sinka et al. [4]).

may be only of secondary importance, or even a non vector in another [14]. For example, An. annularis has a range extending across India, down through South-East Asia, across many of the Indonesian islands down to and including Timor Island [14]. However, it only has a focal role in malaria transmission in selected areas of India. Elsewhere it is considered of little importance [85-91] (hence, An. annularis, along with An. aconitus and An. subpictus; all listed in Table 3 as DVS, are not included in the multi-species maps shown here in Figure 1 and Figure 5, as overall, they do not have as great an impact in malaria transmission as other species in the region). 


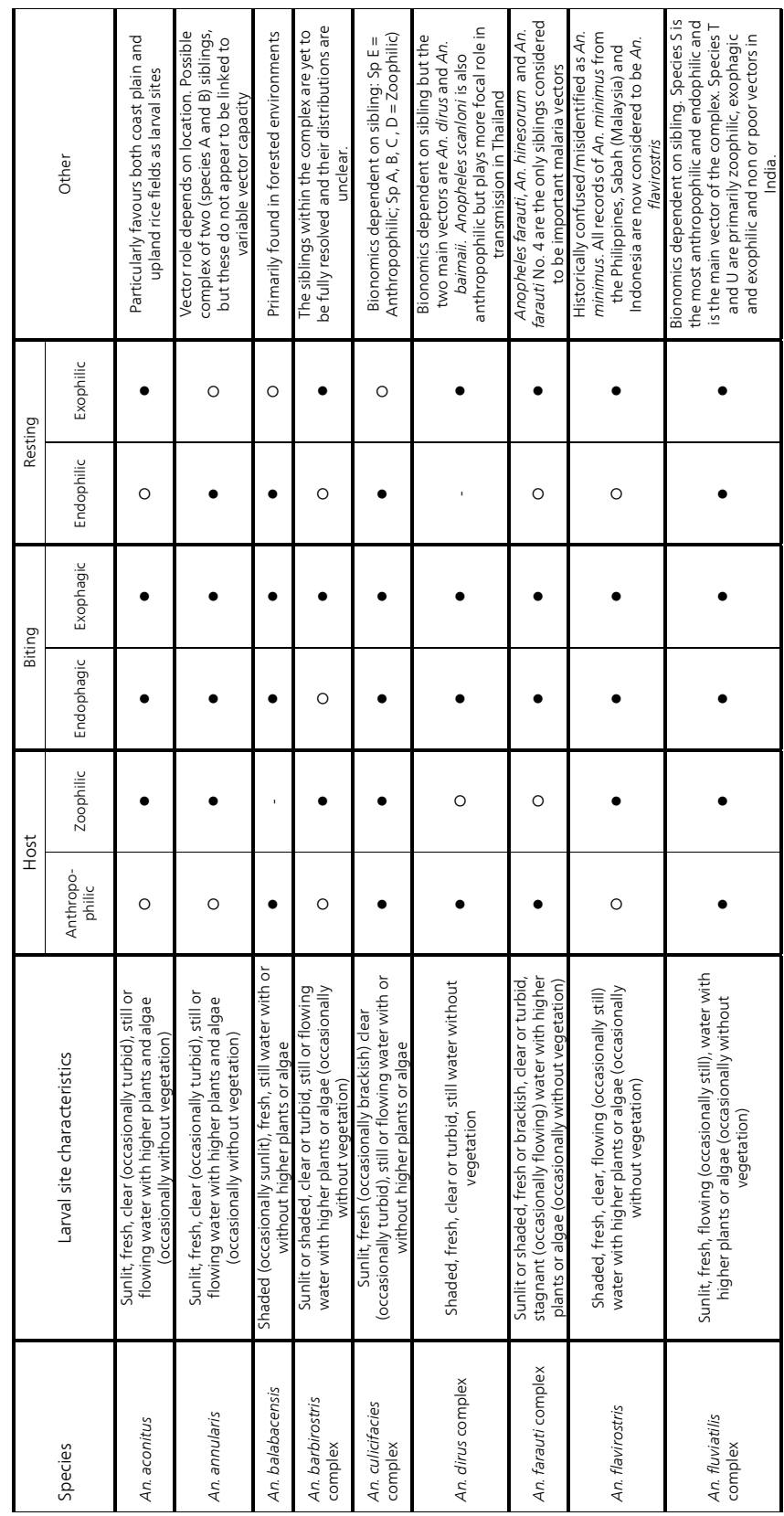

Table 3a. Summary of bionomics of the DVS of the Asian-Pacific (created by cross referencing TAG and literature searches) Filled dot $(\bullet)$ indicates typical behaviour, open dot (०) indicates non-typical behaviour but examples exist, and dashes (-) indicate no data. 


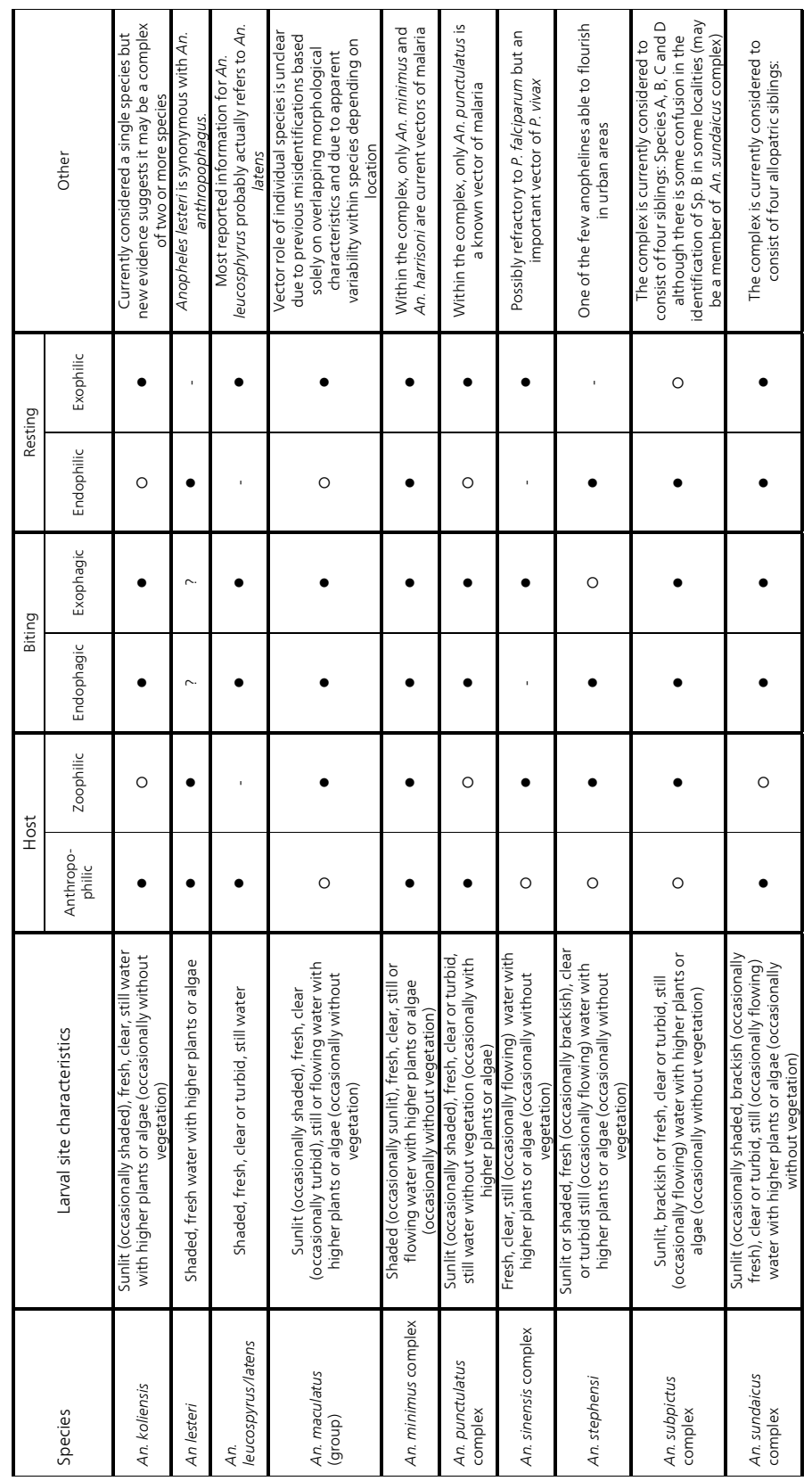

Table 3b. Summary of bionomics of the DVS of the Asian-Pacific (created by cross referencing TAG and literature searches) Filled dot $(\bullet)$ indicates typical behaviour, open dot (०) indicates non-typical behaviour but examples exist, and dashes (-) indicate no data. 
Unfortunately the high number of vectors in this region, and their complexity, have not equated to a higher level of knowledge, despite considerable effort from local scientists as well as from US military entomologists during WWII and the Vietnam War. Indeed, amongst all 41 DVS mapped $[5,14,15]$, the two species with the lowest number of occurrence points, were both from the Asian-Pacific region (An. leucosphyrus/An. latens (12 points) and An. balabacensis (14 points)). There are also limitations when attempting to categorise vector behaviour as again, some species are very poorly studied, or those data that do exist are compromised by unreliable identifications due to the lack of robust techniques that are now available. Hence the summaries given here should be considered as potentially transient and may be updated as more data is collected and systematic PCR-based assays for species identification are applied [92-94]. Accepting these caveats, it must also be noted that the behavioural information presented is the culmination of a comprehensive review of the published literature combined with the 'on the ground' knowledge of highly competent and experienced experts and as such, do represent the best currently available species distribution maps and bionomics knowledge. Here focus is on the species and species complexes designated as the most influential across the region, including An. culicifacies, An. fluviatilis and An. stephensi across the Indian subcontinent; An. dirus and An. minimus within south-east Asia and the DVS members of the Punctulatus Group in the Pacific region. More detailed bionomics information and single species distribution maps for all 19 Asian-Pacific DVS are given in Sinka et al. [14].

\subsection{Indian subcontinent (Bangladesh, Bhutan, India, Nepal, Pakistan, Sri Lanka)}

The Indian subcontinent is densely populated giving rise to very high figures for the population at risk from malaria, however, the levels of risk are typically lower than those found in sub-saharan Africa. The majority of people at risk are living in areas of low endemicity $(<5 \%$ prevalence) or areas of unstable malaria transmission where the disease is not endemic. This is true for both falciparum and vivax malaria. A smaller number of people living in India itself are at risk of much higher levels of falciparum malaria (>40\% prevalence), possibly equalling the levels of risk found in sub-saharan Africa although there is a need for more data to support these figures [82].

The range of the An. culicifacies complex extends far beyond the Indian subcontinent; it also encompasses large areas of Southeast Asia including Vietnam, Cambodia, Lao PDR and southern China and reaches as far as Yemen in the Middle East with a small distribution in Eritrea as well as Nepal, India, Pakistan and Sri Lanka [14] (Figure 1). Despite this extensive distribution, the complex has only been studied in any detail in India and Sri Lanka [95-100]. Of the five species (A, B, C, D, E) of the complex, four are considered vectors in India (A, C, D and E) [101]. Of these four, species $\mathrm{E}$ is a particularly efficient vector due to its highly anthropophilic and endophilic behaviour and is considered the most important vector of both $P$. falciparum and P. vivax in southern India and Sri Lanka $[102,103]$. The remaining three species (A, C and D) are primarily zoophilic and tend to be considered as playing more minor roles in malaria transmission [97]. Indeed, the highly zoophilic behaviour of Species B means it is often considered a non-vector [99, 104]. 
Members of the complex are found at a wide range of altitudes, from plains to hilly and mountainous areas [100]. The habitats they utilise are also varied and include forested and deforested ecotypes and irrigated areas. Consequentially, the larval sites they inhabit are also wide-ranging and include man-made habitats such as irrigation canals, borrow pits, domestic wells, tanks and gutters as well as natural sites such as stream margins and rock pools [96, 100, 101, 104-107]. A tolerance to brackish water has also been reported [96, 108], although freshwater sites appear to be preferred. With many aspects of behaviour dependent on sibling, further investigations, coupled with confirmed identifications of each species, are needed before targeted vector control can be applied.

Again, despite a large distribution (Figure 1) [14], the behaviour and ecology of the An. fluviatilis complex has only been studied in any detail in two countries: India and Iran. The complex consists of three species, currently and informally designated species $S, T$ and $U$ [109] and an as yet unconfirmed form $V$ [110]. The complex is distributed widely across the forested hills and mountains of southwestern Asia (Iran, Pakistan, Afghanistan, India, Nepal, Bangladesh and Myanmar) [104, 111-114]. Members of the complex also exhibit behavioural differences, with the anthropophilic and endophilic An. fluviatilis S categorised as a highly efficient vector in India [112], whereas both the zoophilic Species T and U, which also tend to feed and rest outdoors, are considered poor or non-vectors $[115,116]$. However, species $\mathrm{T}$ is considered an important vector in Pakistan, Nepal and Iran [117, 118]. The larvae of this complex are associated with slow-flowing water in streams or river margins [119-124] (Table 3a).

The ability of the larval stages of An. stephensi (Table 3b) to develop in urban areas, making use of artificial containers such as domestic wells, overhead water tanks, room coolers, cisterns and roof gutters and in water bodies in construction sites and other industrial localities, brings malaria transmission into densely populated areas including the major cities of India such as Delhi $[125,126]$. In general, malaria is considered to be a disease confined to rural environments, as a simple consequence of the tendency of anophelines to search for clean and unpolluted larval habitats and thus the existence of An. stephensi in such areas is a defining characteristic of the species.

Anopheles stephensi is found across the Indian subcontinent [14], extending from the Arabian Peninsula, through Iran and Iraq, across to Bangladesh, southern China, Myanmar and Thailand (Figure 1) [127-129]. It is typically described as an endophilic and endophagic species despite a tendency to bite outdoors during warmer months when people are more active outdoors [130,131]. Host availability seems to be a driver to a variable anthropophily for this species, and therefore in urban areas, there appears to be a greater tendency for biting humans $[132,133]$, and therefore an increased risk of malaria transmission.

\subsection{Southeast Asia (Cambodia, Laos, Myanmar, Thailand, Vietnam)}

Human populations in Southeast Asia, with the exception of Myanmar, are typically exposed to low levels of falciparum and vivax malaria endemicity, unstable malaria transmission or are living in malaria-free areas. The majority of the population in Myanmar live in areas with low malaria endemicity but significant numbers live in areas of moderate (5-40\% prevalence) and high $(>40 \%$ falciparum prevalence or $>7 \%$ vivax prevalence) risk. There is increasing 
evidence that knowlesi malaria is transmitted from monkeys to humans in this region, particularly in the South, but the level of risk is currently unmeasured [82, 83, 134, 135].

The Dirus and Minimus complexes both contain species considered particularly efficient in transmitting malaria. Indeed, the An. dirus complex, due to its longevity and the highly anthropophilic behaviour of its members (Table 3a), is considered to be the dominant vector group in any area where its species exist [136]. However, due to its close relationship with members of the Leucosphyrus Complex, there has been considerable confusion in its identity in the published literature [137]. Species of the An. dirus complex are forest dwellers, existing in mountains and foothills, cultivated forests and forest fringes. There are eight members, $A n$. dirus (formerly An. dirus species A), An. cracens (formerly sp. B), An. scanloni (formerly sp. C), An. baimaii (formerly sp. D), An. elegans (formerly sp. E), An. nemophilous (formerly sp. F), An. takasagoensis and the recently added species informally named An. Aff. Takasagoensis [138-142]. Of these species, An. dirus and An. baimaii are vectors of particular note [143-146]. As mentioned above, they are both highly anthropophilic, but their efficiency in transmitting both vivax and falciparum malaria is enhanced through biting humans both in and outdoors and of avoiding most conventional control methods by resting mainly outdoors (Table 3a) [111, 143, 145, 147-150].

Larvae are typically found in small, temporary, shallow and shaded pools of fresh water within the forest environment, such as puddles, pits, animal footprints, wheel ruts, hollow logs and slow flowing streams (Table 3a) [151-154].

Species of the An. minimus complex are also found in the hilly forested regions, but unlike the Dirus Complex, are restricted to mainland Southeast Asia (Figure 1) [14]. The complex contains three sibling species, An. minimus (formerly species A), An. harrisoni (formerly sp. C) and An. yaeyamaensis (formerly sp. E) [155-157]. This latter species has a very restricted distribution, only being found in the Ryukyu Archipelago in southern Japan, where it was considered a major malaria vector before the successful eradication of the disease in 1962 [158, 159]. Both An. minimus and An. harrisoni are, however, still considered primary vectors across their range, which encompasses much of Southeast Asia [14], although all historical records of An. minimus in Indonesia are now considered to actually be An. flavirostris. Anopheles minimus has a more adaptable nature than An. harrisoni allowing it to occupy a large variety of habitats, including dense canopy forests to open rice fields [14] and therefore has a greater distribution. Anopheles harrisoni tends to be restricted to deforested agricultural sites [160, 161]. Anopheles minimus is also highly variable in its behaviour (Table $3 b$ ), being an opportunistic mosquito, although in some reports this may be a consequence of the species complex not being fully identified [160]. Larvae of the An. minimus complex are found in small or moderate streams with slow-running, clear water. Females lay their eggs in the partially shaded grassy margins (Table 3b)[162-165]. Larvae have also been found in water containers in Hanoi [166].

Anopheles minimus is considered primarily anthropophilic, but its choice of blood meal can also be influenced by the availability of alternative animal hosts such as domestic cattle $[148,167$, 168]. Biting habit is also variable (Table 3b), and dependent on location, with reports of endophagic behaviour in India, Thailand and central Vietnam, but exophagic behaviour in Cambodia and northern Vietnam [148, 165, 169]. The same is found for resting behaviour, 
although there appears to be a large influence of the use of IRS on resting location and population densities for this species [170, 171]. Overall, An. harrisoni appears more consistent in behaviour, generally reported as exophagic, exophilic and zoophilic and thus potentially the less dominant vector $[172,173]$.

\subsection{Asia-Pacific (Indonesia, Papua New Guinea, Philippines, Solomon Islands, Vanuatu, Timor Leste)}

Human populations in the Asia-Pacific, with the exception of Papua New Guinea and Indonesian Papua, typically live in areas with low levels of falciparum and vivax malaria endemicity $(<5 \%$ prevalence), or unstable malaria transmission or that are malaria-free. The majority of the population in Papua New Guinea live in areas with low malaria endemicity ( $<5 \%$ prevalence) but significant numbers live in areas of moderate (5-40\% prevalence) risk. $[82,83]$.

The DVS in the Asia-Pacific region (as categorised here) are dominated by three of the 12 members of the Punctulatus Group, namely An. farauti complex, An. koliensis and An. punctulatus complex (Figure 5). Anopheles farauti complex has the widest distribution of these vectors (and of the Punctulatus Group as a whole), extending from the Maluku island group (Indonesia) in the west to Vanuatu in the east, including northern Australia in between. Of the eight species within the An. farauti complex, only three are considered to be main vectors, $A n$. farauti s.s., An. hinesorum (formerly An. farauti No. 2) and An. farauti No. 4, although there is some, albeit limited and circumstantial, evidence of An. farauti No. 6 as a primary vector in the highlands, river valleys and intramontane plains of New Guinea [174, 175].

Despite being the most studied member of the Punctulatus Group, there are still many unknowns regarding the ecology and behaviour of the species of the An. farauti complex, with added uncertainty due to apparent variability in behaviour depending on location (based on reports of undifferentiated members of the complex). However, there are some trends that appear relatively consistent, for example, members seem to be mainly anthropophilic, although they will feed on domestic livestock, birds and other animals where available (Table 3a) [14]. Both endo- and exophagic feeding on humans has been reported, and some, albeit limited, endophilic behaviour. On the whole, females tend to be early biters $(18.00-20.00)$, biting and resting outdoors [14, 176].

The larvae of An. farauti complex are able to make use of a large variety of water sources, both sunlit and shaded, but tend to be found in natural, rain-fed temporary pools through to semipermanent/permanent bodies of ground water, often with floating or emergent vegetation. Within the complex, a defining trait of An. farauti s.s. is its ability to tolerate brackish larval sites, and hence this species is found mainly on the coast in pools within mangroves containing high organic debris and subject to tidal fluctuations. They are also found in natural swamps, oxbows, fish ponds, ditches, borrow pits and pools along stream or river margins [14]. Other members of the complex may have greater or lesser salinity tolerance, but this is one uncertainty that still needs to be confirmed, along with many other aspects of behaviour within the complex. 
Anopheles koliensis plays an important role in transmitting malaria wherever it is found, possibly due to its strong anthropophily (Table $3 b$ ). Its range is essentially limited to New Guinea Island (Figure 5) with only a patchy distribution in the Solomon Islands, where it is absent in some areas despite a presence of apparently suitable environments [177-179]. Where it is found, it will bite in or outdoors, but is rarely found resting indoors [180]. The larvae of this species are found in more permanent habitats than those of either the An. farauti or An. punctulatus complexes [180, 181]. Typical larval sites include sunlit irrigation ditches, and ponds containing floating and/or emergent vegetation, often in close association with humans. They are never found in brackish water [14].

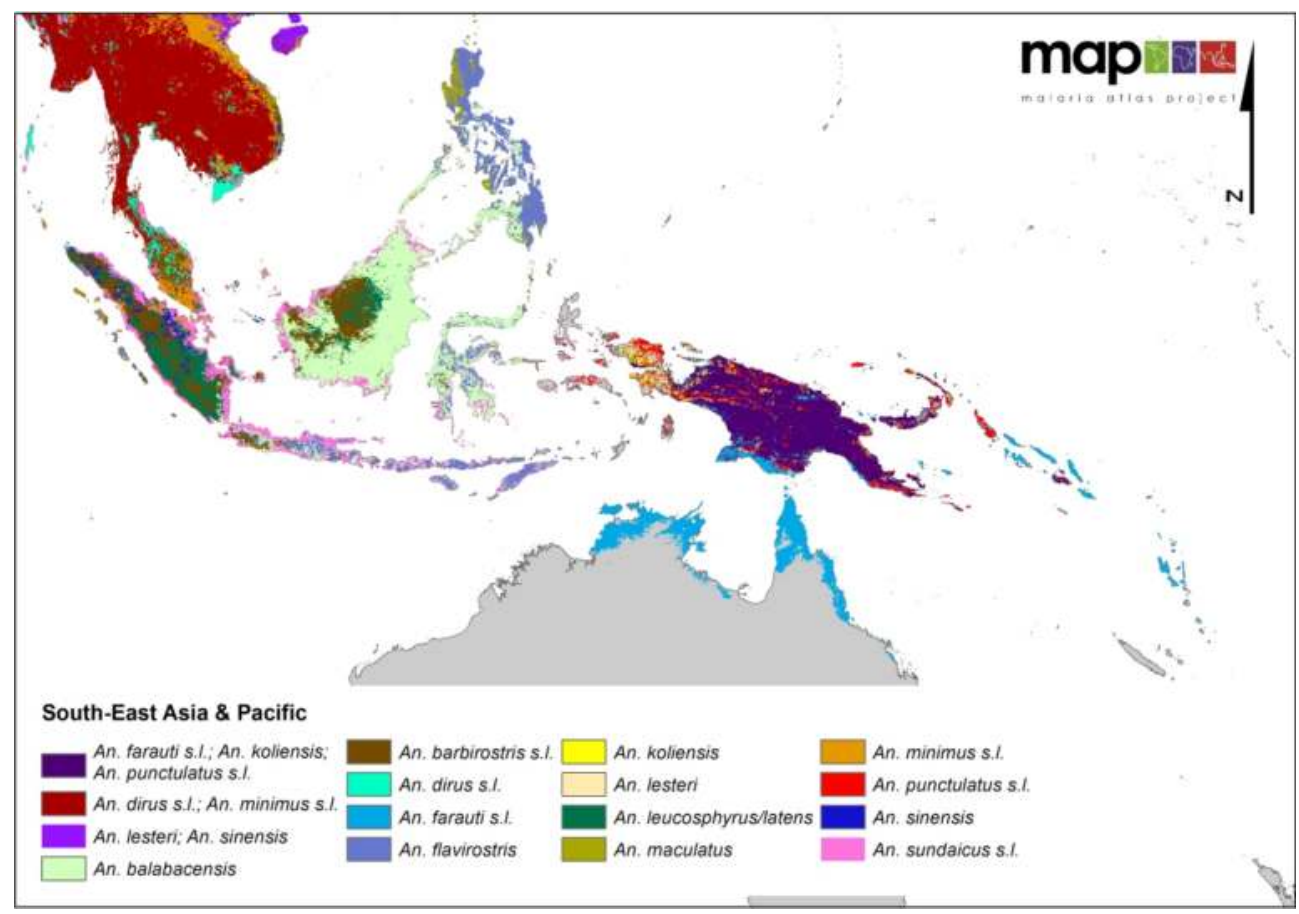

Figure 5. Multi-species map of South-East Asia and the Asia-Pacific region indicating the distribution of 13 DVS of particular importance. (map reproduced from Sinka et al. [4]).

The last DVS in this region is a member of the An. punctulatus complex. The complex contains two species, An. punctulatus and An. sp. near punctulatus [182] of which the latter is relatively uncommon and restricted to a few remote highland localities on New Guinea Island where little is known of its ability to transmit malaria. On the other hand, Anopheles punctulatus is a highly efficient malaria vector across much of its range, which extends within lowland valleys and plains, and up to altitudes of 2000m across New Guinea Island and the Solomon Islands [174], although its impact and importance as a vector appears reduced in this eastward end of its range $[14,178,179]$. As with other vectors within the Punctulatus Group, An. punctulatus 
feeds readily on humans both in and outdoors and is mainly found resting outdoors (Table 3b) $[181,183,184]$. This species is particularly adept at exploiting disturbed environments, such as those caused by land clearance or areas subject to drought conditions, where receding rivers result in small temporary pools rapidly colonised by larvae. Such colonisations can result in explosive adult populations and subsequent severe and unpredictable outbreaks of malaria $[185,186]$. The typical larval sites utilised by this species reflect the conditions found in such disturbed ecologies, i.e. scattered temporary pools of fresh water, generally sunlit and shallow, containing either clear or turbid water with little or no vegetation [14]. Eggs can cope with some level of desiccation and larvae can survive in damp mud for several days during drought conditions [183]. They are also able to withstand high water temperatures (over $40^{\circ} \mathrm{C}$ ) where they grow rapidly with particularly short development time (5-9 days to adults), occasionally resorting to cannibalism to survive, (Bangs, pers com; [14]).

\section{Map methodology}

A full description of the methodology used to create the individual and multi-species maps is given in Sinka et al [15] and Sinka et al [4].

The maps presented here were created using the Boosted Regression Tree (BRT) environmental niche modelling method $[187,188]$. This method uses spatially defined presence data and environmental and climatic variables to identify the conditions that typify a species' habitat. The model then identifies all locations where such conditions exist and therefore other localities where the species could potentially occur (i.e. its fundamental niche). It also provides an estimate of the probability of occurrence, i.e. applying a numerical value to indicate the conditions within the acceptable range of a species. The multi-species maps show only presence pixels with a probability value greater than 0.5 for each species.

To create the multi-species maps, the individual species distributions were overlaid ensuring the most dominant species (established through consultation with a technical advisory group of vector experts) was uppermost. Where more than one species was considered dominant in an area the species distributions were merged.

\section{Conclusions}

The maps given in this chapter are presented with the caveat that they represent only the beginning of a process to establish the distribution of these vectors. As with all species distribution modelling, the accuracy of the output is limited by the amount and quality of the data that is available to the model. The data must be accurately geo-referenced and reflect the true and full identity of the species to be modelled. Our maps were created using the most comprehensive database of species occurrence currently available, yet still, for many of the DVS, the quality of the data is ambiguous and the quantity is poor. However, as more reliable and repeatable methods of species identification are developed, species occurrence data and 
the corresponding bionomics will be better understood as the taxonomy of many of these species are resolved. Moreover, a greater commitment for data sharing between research groups, public health officials, modellers and map makers is beginning to increase the quantity and quality of data available and subsequently, increasingly accurate maps and a greater understanding of transmission dynamics, combined with the benefits of targeted vector control, is making the prospect of the global elimination of malaria a much more realistic goal.

\section{Acknowledgements}

The information detailed in this chapter is based on a study originally conceived by Simon Hay and completed in collaboration with an esteemed group of vector experts, who were generous with both their time and expertise, and without whom, the bionomics sections would be a great deal shorter and the maps a great deal poorer. I would therefore like to thank Michael J. Bangs, Theeraphap Chareonviriyaphap, Maureen Coetzee, Ralph E. Harbach, Janet Hemingway, Sylvie Manguin, Charles M. Mbogo and Yasmin Rubio-Palis. Thanks also to Catherine Moyes for providing malaria parasite backgound information and for proof reading this work.

\section{Author details}

Marianne E. Sinka*

Address all correspondence to: marianne.sinka@zoo.ox.ac.uk

Spatial Ecology and Epidemiology Group, Tinbergen Building, Department of Zoology, University of Oxford, South Parks Road, Oxford, UK

\section{References}

[1] Genus Anopheles Meigen, 1818. Mosquito Taxonomic Inventory [database on the Internet]2011 [cited 2 December 2011]. Available from: http://mosquito-taxonomic-inventory.info.

[2] Service MW, Townson H. The Anopheles vector. In: Gilles HM, Warrell DA, editors. Essential Malariology. Fourth edition ed. London: Arnold; 2002. p. 59-84.

[3] Hay SI, Sinka ME, Okara RM, Kabaria CW, Mbithi PM, Tago CC, Benz D, Gething PW, Howes RE, Patil AP, Temperley WH, Bangs MJ, Chareonviriyaphap T, Elyazar IR, Harbach RE, Hemingway J, Manguin S, Mbogo CM, Rubio-Palis Y, Godfray HC. Developing global maps of the dominant Anopheles vectors of human malaria. PLoS Med. 2010;7(2):e1000209. 
[4] Sinka ME, Bangs MJ, Manguin S, Rubio-Palis Y, Chareonviriyaphap T, Coetzee M, Mbogo CM, Hemingway J, Patil AP, Temperley WH, Gething PW, Kabaria CW, Burkot TR, Harbach RE, Hay SI. A global map of dominant malaria vectors. Parasit Vectors. 2012;5(69).

[5] Sinka ME, Bangs MJ, Manguin S, Coetzee M, Mbogo CM, Hemingway J, Patil AP, Temperley WH, Gething PW, Kabaria CW, Okara RM, Van Boeckel T, Godfray HCJ, Harbach RE, Hay SI. The dominant Anopheles vectors of human malaria in Africa, Europe and the Middle East: occurrence data, distribution maps and bionomic précis. Parasit Vectors. 2010;3(1):117.

[6] Harbach RE. The classification of genus Anopheles (Diptera: Culicidae): a working hypothesis of phylogenetic relationships. Bull Entomol Res. 2004;94(6):537-53.

[7] Collins FH, Paskewitz SM. Malaria: current and future prospects for control. Annu Rev Entomol. 1995;40:195-219.

[8] Service MW. Appendix II. Characteristics of some major Anopheles vectors of human malaria. In: Gilles HM, Warrell DA, editors. Bruce-Chwatt's Essential Malariology. Third ed. London: Edward Arnold; 1993. p. 305-10.

[9] Service MW. The Anopheles vector. In: Gilles HM, Warrell DA, editors. Bruce-Chwatt's Essential Malariology. Third ed. London: Edward Arnold; 1993. p. 96-123.

[10] Mouchet J, Carnevale P, Coosemans M, Julvez J, Manguin S, Richard-Lenoble D, Sircoulon J. Biodiversité du paludisme dans le monde. Montrouge, France: John Libbey Eurotext; 2004.

[11] Kiszewski A, Mellinger A, Spielman A, Malaney P, Sachs SE, Sachs J. A global index representing the stability of malaria transmission. Am J Trop Med Hyg. 2004;70(5): 486-98.

[12] White GB. Malaria. Geographical distribution of arthropod-borne diseases and their principal vectors Geneva: World Health Organization, Division of Vector Biology and Control1989 Contract No.: WHO/VBC/89967.

[13] Manguin S, Carnevale P, Mouchet J, Coosemans M, Julvez J, Richard-Lenoble D, Sircoulon J. Biodiversity of malaria in the world. Montrouge, France: John Libbey Eurotext; 2008.

[14] Sinka ME, Bangs MJ, Manguin S, Chareonviriyaphap T, Patil AP, Temperley WH, Gething PW, Elyazar IR, Kabaria CW, Harbach RE, Hay SI. The dominant Anopheles vectors of human malaria in the Asia-Pacific region: occurrence data, distribution maps and bionomic précis. Parasit Vectors. 2011;4:89.

[15] Sinka ME, Rubio-Palis Y, Manguin S, Patil AP, Temperley WH, Gething PW, Van Boeckel T, Kabaria CW, Harbach RE, Hay SI. The dominant Anopheles vectors of human malaria in the Americas: occurrence data, distribution maps and bionomic précis. Parasit Vectors. 2010 Aug 16;3(1):72. 
[16] Manguin S, Boëte C. Global impact of mosquito biodiversity, human vector-borne diseases and environmental change. In: Lopez-Pujol J, (ed.). The importance of biological interactions in the study of biodiversity. Rijeka, Croatia: InTech open access Publisher; 2011. p. 390.

[17] Hay SI, Guerra CA, Gething PW, Patil AP, Tatem AJ, Noor AM, Kabaria CW, Manh BH, Elyazar IR, Brooker S, Smith DL, Moyeed RA, Snow RW. A world malaria map: Plasmodium falciparum endemicity in 2007. PLoS Med. 2009 Mar 24;6(3):e1000048.

[18] WHO/PAHO (World Health Organization/Pan American Health Organization). Malaria in the Americas: time series epidemiological data from 2000 to 2007. Washington DC: Pan American Health Organization, Regional Office for the Americas 2008.

[19] WHO/PAHO (World Health Organization/Pan American Health Organization). Regional strategic plan for malaria in the Americas 2006-2010. Washington, DC: Pan American Health Organization, Regional Office for the Americas 2006.

[20] WHO (World Health Organization). Global strategic framework for integrated vector management. Geneva: World Health Organization 2004.

[21] Conn JE, Wilkerson RC, Segura MN, de Souza RT, Schlichting CD, Wirtz RA, Povoa $\mathrm{MM}$. Emergence of a new neotropical malaria vector facilitated by human migration and changes in land use. Am J Trop Med Hyg. 2002;66(1):18-22.

[22] Grillet ME, Montañez H, Berti J. Estudio biosistemático y ecológico de Anopheles aquasalis y sus implicaciones para el control de la malaria en el estado Sucre: II. Ecología de sus criaderos. Bol Dir Malariol San Amb 1998;38(1):38-46.

[23] Manguin S, Peyton EL, James AC, Roberts DR. Apparent changes in the abundance and distribution of Anopheles species on Grenada Island. J Am Mosq Control Assoc. 1993;9(4):403-7.

[24] Brochero HL, Rey G, Buitrago LS, Olano VA. Biting activity and breeding sites of Anopheles species in the municipality Villavicencio, Meta, Colombia. J Am Mosq Control Assoc. 2005;21(2):182-6.

[25] Moreno JE, Rubio-Palis Y, Acevedo P. Identificación de criaderos de anofelinos en un área endémica del estado Bolívar, Venezuela. Bol Malariol San Amb 2000;40:21-30.

[26] Moreno JE, Rubio-Palis Y, Paez E, Perez E, Sanchez V. Abundance, biting behaviour and parous rate of anopheline mosquito species in relation to malaria incidence in goldmining areas of southern Venezuela. Med Vet Entomol. 2007 Dec;21(4):339-49.

[27] Manguin S, Roberts DR, Peyton EL, Rejmankova E, Pecor J. Characterization of Anopheles pseudopunctipennis larval habitats. J Am Mosq Control Assoc. 1996;12(4): 619-26.

[28] Rubio-Palis Y, Zimmerman RH. Ecoregional classification of malaria vectors in the neotropics. J Med Entomol. 1997 Sep;34(5):499-510. 
[29] Bond JG, Novelo-Gutierrez R, Ulloa A, Rojas JC, Quiroz-Martinez H, Williams T. Diversity, abundance, and disturbance response of Odonata associated with breeding sites of Anopheles pseudopunctipennis (Diptera: Culicidae) in southern Mexico. Environ Entomol. 2006 Dec;35(6):1561-8.

[30] Bond JG, Quiroz-Martinez H, Rojas JC, Valle J, Ulloa A, Williams T. Impact of environmental manipulation for Anopheles pseudopunctipennis Theobald control on aquatic insect communities in southern Mexico. J Vector Ecol. 2007 Jun;32(1):41-53.

[31] Bond JG, Rojas JC, Arredondo-Jimenez JI, Quiroz-Martinez H, Valle J, Williams T. Population control of the malaria vector Anopheles pseudopunctipennis by habitat manipulation. Proc Biol Sci. 2004 Oct 22;271(1553):2161-9.

[32] Hay SI, Guerra CA, Tatem AJ, Atkinson PM, Snow RW. Urbanization, malaria transmission and disease burden in Africa. Nat Rev Microbiol. 2005 Jan;3(1):81-90.

[33] Hay SI, Rogers DJ, Toomer JF, Snow RW. Annual Plasmodium falciparum entomological inoculation rates (EIR) across Africa: literature survey, internet access and review. Trans R Soc Trop Med Hyg. 2000;94(2):113-27.

[34] Fontenille D, Simard F. Unravelling complexities in human malaria transmission dynamics in Africa through a comprehensive knowledge of vector populations. Comp Immunol Microbiol Infect Dis. 2004 Sep;27(5):357-75.

[35] Guerra CA, Gikandi PW, Tatem AJ, Noor AM, Smith DL, Hay SI, Snow RW. The limits and intensity of Plasmodium falciparum transmission: implications for malaria control and elimination worldwide. PLoS Med. 2008 Feb;5(2):e38.

[36] Hay SI, Okiro EA, Gething PW, Patil AP, Tatem AJ, Guerra CA, Snow RW. Estimating the global clinical burden of Plasmodium falciparum malaria in 2007. PLoS Med. 2010;7(6):e100029.

[37] Coluzzi M. The clay feet of the malaria giant and its African roots: hypotheses and inferences about origin, spread and control of Plasmodium falciparum. Parassitologia. 1999 Sep;41(1-3):277-83.

[38] Gillies MT, de Meillon B. The Anophelinae of Africa South of the Sahara (Ethiopian zoogeographical region). 2nd ed. Johannesburg: The South African Institute for Medical Research; 1968.

[39] Temu EA, Minjas JN, Coetzee M, Hunt RH, Shift CJ. The role of four anopheline species (Diptera: Culicidae) in malaria transmission in coastal Tanzania. Trans R Soc Trop Med Hyg. 1998 Mar-Apr;92(2):152-8.

[40] Gillies MT, Coetzee M. A supplement to the Anophelinae of Africa south of the Sahara (Afrotropical region). Johannesburg: The South African Institute for Medical Research; 1987.

[41] Cuamba N, Mendis C. The role of Anopheles merus in malaria transmission in an area of southern Mozambique. J Vector Borne Dis. 2009 Jun;46(2):157-9. 
[42] Bryan JH. Anopheles gambiae and A. melas at Brefet, The Gambia, and their role in malaria transmission. Ann Trop Med Parasitol. 1983 Feb;77(1):1-12.

[43] Charlwood JD, Smith T, Kihonda J, Heiz B, Billingsley PF, Takken W. Densityindependent feeding success of malaria vectors (Diptera: Culicidae) in Tanzania. Bull Entomol Res. 1995 Mar;85(1):29-35.

[44] Gelfand HM. Anopheles gambiae Giles and Anopheles melas Theobald in a coastal area of Liberia, West Africa. Trans R Soc Trop Med Hyg. 1955 Nov;49(6):508-27.

[45] Muirhead-Thomson RC. Studies on salt-water and fresh-water Anopheles gambiae on the East African coast. Bull Entomol Res. 1951;41:487-502.

[46] Muirhead-Thomson RC. Studies on Anopheles gambiae and A. melas in and around Lagos. Bull Entomol Res. 1948;38:527-58.

[47] Muirhead-Thomson RC. Studies on the breeding places and control of Anopheles gambiae and A. gambiae var. melas in coastal districts of Sierra Leone. Bull Entomol Res. 1946;36:185-252.

[48] Hunt RH, Coetzee M, Fettene M. The Anopheles gambiae complex: a new species from Ethiopia. Trans R Soc Trop Med Hyg. 1998 Mar-Apr;92(2):231-5.

[49] Coluzzi M, Petrarca V, Dideco MA. Chromosomal inversion intergradation and incipient speciation in Anopheles gambiae. B Zool. 1985;52(1-2):45-63.

[50] Della Torre A, Fanello C, Akogbeto M, Dossou-yovo J, Favia G, Petrarca V, Coluzzi M. Molecular evidence of incipient speciation within Anopheles gambiae s.s. in West Africa. Insect Mol Biol. 2001;10(1):9-18.

[51] Fanello C, Petrarca V, della Torre A, Santolamazza F, Dolo G, Coulibaly M, Alloueche A, Curtis CF, Toure YT, Coluzzi M. The pyrethroid knock-down resistance gene in the Anopheles gambiae complex in Mali and further indication of incipient speciation within An. gambiae s.s. Insect Mol Biol. 2003;12(3):241-5.

[52] Caputo B, Nwakanma D, Jawara M, Adiamoh M, Dia I, Konate L, Petrarca V, Conway DJ, Della Torre A. Anopheles gambiae complex along The Gambia river, with particular reference to the molecular forms of An. gambiae s.s. Malar J. 2008 Sep 22;7(1):182.

[53] Costantini C, Ayala D, Guelbeogo WM, Pombi M, Some CY, Bassole IH, Ose K, Fotsing JM, Sagnon N, Fontenille D, Besansky NJ, Simard F. Living at the edge: biogeographic patterns of habitat segregation conform to speciation by niche expansion in Anopheles gambiae. BMC Ecol. 2009 May 21;9(1):16.

[54] Della Torre A, Costantini C, Besansky NJ, Caccone A, Petrarca V, Powell JR, Coluzzi M. Speciation within Anopheles gambiae-the glass is half full. Science. 2002 Oct 4;298(5591):115-7.

[55] Della Torre A, Tu ZJ, Petrarca V. On the distribution and genetic differentiation of Anopheles gambiae s.s. molecular forms. Insect Biochem Molec. 2005 Jul;35(7):755-69. 
[56] Diabate A, Dabire RK, Heidenberger K, Crawford J, Lamp WO, Culler LE, Lehmann T. Evidence for divergent selection between the molecular forms of Anopheles gambiae: role of predation. BMC Evol Biol. 2008 Jan 11;8(1):5.

[57] Diabate A, Dabire RK, Kim EH, Dalton R, Millogo N, Baldet T, Simard F, Gimnig JE, Hawley WA, Lehmann T. Larval development of the molecular forms of Anopheles gambiae (Diptera: Culicidae) in different habitats: a transplantation experiment. J Med Entomol. 2005;42(4):548-53.

[58] Sharp BL, Lesueur D. Behavioral variation of Anopheles arabiensis (Diptera: Culicidae) populations in Natal, South Africa. Bull Entomol Res. 1991 Mar;81(1):107-10.

[59] White GB. Anopheles gambiae complex and disease transmission in Africa. Trans R Soc Trop Med Hyg. 1974;68(4):278-301.

[60] White GB. The Anopheles gambiae complex and malaria transmission around Kisumu, Kenya. Trans R Soc Trop Med Hyg. 1972;66(4):572-81.

[61] White GB, Rosen P. Comparative studies on sibling species of Anopheles gambiae Giles complex (Dipt: Culicidae). II. Ecology of Species A and B in savanna around Kaduna, Nigeria, during transition from wet to dry season. Bull Entomol Res. 1973;62(4):613-25.

[62] Tirados I, Costantini C, Gibson G, Torr SJ. Blood-feeding behaviour of the malarial mosquito Anopheles arabiensis: implications for vector control. Med Vet Entomol. 2006;20(4):425-37.

[63] Shililu J, Mbogo C, Ghebremeskel T, Githure J, Novak R. Mosquito larval habitats in a semi-arid ecosystem in Eritrea: impact of larval habitat management on Anopheles arabiensis populations. Am J Trop Med Hyg. 2007 Jan;76(1):103-10.

[64] Shililu J, Ghebremeskel T, Seulu F, Mengistu S, Fekadu H, Zerom M, Ghebregziabiher A, Sintasath D, Bretas G, Mbogo C, Githure J, Brantly E, Novak R, Beier JC. Larval habitat diversity and ecology of anopheline larvae in Eritrea. J Med Entomol. 2003;40(6): 921-9.

[65] Kamau L, Munyekenye GO, Vulule JM, Lehmann T. Evaluating genetic differentiation of Anopheles arabiensis in relation to larval habitats in Kenya. Infect Genet Evol. 2007 Mar;7(2):293-7.

[66] Abdullah MA, Merdan AI. Distribution and ecology of the mosquito fauna in the southwestern Saudi Arabia. J Egypt Soc Parasitol. 1995 Dec;25(3):815-37.

[67] Mwangangi JM, Muturi EJ, Shililu JI, Muriu S, Jacob B, Kabiru EW, Mbogo CM, Githure JI, Novak RJ. Environmental covariates of Anopheles arabiensis in a rice agroecosystem in Mwea, Central Kenya. J Am Mosq Control Assoc. 2007 Dec;23(4):371-7.

[68] Mwangangi JM, Muturi EJ, Shililu J, Muriu SM, Jacob B, Kabiru EW, Mbogo CM, Githure J, Novak R. Survival of immature Anopheles arabiensis (Diptera: Culicidae) in aquatic habitats in Mwea rice irrigation scheme, central Kenya. Malar J. 2006;5:114. 
[69] Mwangangi J, Shililu J, Muturi E, Gu WD, Mbogo C, Kabiru E, Jacob B, Githure J, Novak R. Dynamics of immature stages of Anopheles arabiensis and other mosquito species (Diptera: Culicidae) in relation to rice cropping in a rice agro-ecosystem in Kenya. J Vector Ecol. 2006 Dec;31(2):245-51.

[70] Mutero CM, Blank H, Konradsen F, van der Hoek W. Water management for controlling the breeding of Anopheles mosquitoes in rice irrigation schemes in Kenya. Acta Trop. 2000;76(3):253-63.

[71] Ameneshewa B, Service MW. Resting habits of Anopheles arabiensis in the Awash River valley of Ethiopia. Ann Trop Med Parasitol. 1996;90(5):515-21.

[72] Coluzzi M, Sabatini A, Petrarca V, Di Deco MA. Chromosomal differentiation and adaptation to human environments in the Anopheles gambiae complex. Trans R Soc Trop Med Hyg. 1979;73(5):483-97.

[73] Coetzee M, Fontenille D. Advances in the study of Anopheles funestus, a major vector of malaria in Africa. Insect Biochem Mol Biol. 2004 Jul;34(7):599-605.

[74] Cohuet A, Simard F, Toto JC, Kengne P, Coetzee M, Fontenille D. Species identification within the Anopheles funestus group of malaria vectors in Cameroon and evidence for a new species. Am J Trop Med Hyg. 2003;69(2):200-5.

[75] Weeto MM, Koekemoer LL, Kamau L, Hunt RH, Coetzee M. Evaluation of a speciesspecific PCR assay for the Anopheles funestus group from eleven African countries and Madagascar. Trans R Soc Trop Med Hyg. 2004 Mar;98(3):142-7.

[76] Antonio-Nkondjio C, Kerah CH, Simard F, Awono-Ambene P, Chouaibou M, Tchuinkam T, Fontenille D. Complexity of the malaria vectorial system in Cameroon: contribution of secondary vectors to malaria transmission. J Med Entomol. 2006;43(6): 1215-21.

[77] Awolola TS, Oyewole IO, Koekemoer LL, Coetzee M. Identification of three members of the Anopheles funestus (Diptera: Culicidae) group and their role in malaria transmission in two ecological zones in Nigeria. Trans R Soc Trop Med Hyg. 2005;99(7):525-31.

[78] Hargreaves K, Koekemoer LL, Brooke BD, Hunt RH, Mthembu J, Coetzee M. Anopheles funestus resistant to pyrethroid insecticides in South Africa. Med Vet Entomol. [Article]. 2000 Jun;14(2):181-9.

[79] Carnevale P, Guillet P, Robert V, Fontenille D, Doannio J, Coosemans M, Mouchet J. Diversity of malaria in rice growing areas of the Afrotropical region. Parassitologia. 1999;41(1-3):273-6.

[80] Chandler JA, Highton RB, Hill MN. Mosquitoes of the Kano Plain, Kenya. I. Results of indoor collections in irrigated and nonirrigated areas using human bait and light traps. J Med Entomol. 1975 Dec 30;12(5):504-10. 
[81] Sogoba N, Doumbia S, Vounatsou P, Bagayoko MM, Dolo G, Traore SF, Maiga HM, Toure YT, Smith T. Malaria transmission dynamics in Niono, Mali: the effect of the irrigation systems. Acta Trop. 2007 Mar;101(3):232-40.

[82] Gething PW, Patil AP, Smith DL, Guerra CA, Elyazar IR, Johnston GL, Tatem AJ, Hay SI. A new world malaria map: Plasmodium falciparum endemicity in 2010. Malar J. 2011;10:378.

[83] Gething PW, Elyazar IRF, Moyes CM, Smith DL, Battle KE, Guerra CA, Patil AP, Tatem AJ, Howes RE, Myers MF, George DB, Horby P, Wertheim HF, Price R, Müller I, Baird JK, Hay SI. A long neglected world malaria map: Plasmodium vivax endemicity in 2010. PLoS Negl Trop Dis. 2012;6(9):e1814.

[84] Guerra CA, Howes RE, Patil AP, Gething PW, Van Boeckel TP, Temperley WH, Kabaria CW, Tatem AJ, Manh BH, Elyazar IRF, Baird KJ, Snow RW, Hay SI. The international limits and population at risk of Plasmodium vivax transmission in 2009. PLoS Negl Trop Dis. 2010;4(8):e774.

[85] Dash AP, Bendley MS, Das AK, Das M, Dwivedi SR. Role of An. annularis as a vector of malaria in inland of Orissa. J Commun Dis. 1982;14:224.

[86] Ghosh KK, Chakraborty S, Bhattacharya S, Palit A, Tandon N, Hati AK. Anopheles annularis as a vector of malaria in rural West Bengal. Indian J Malariol. 1985;22(2):65-9.

[87] Gunasekaran K, Sahu SS, Parida SK, Sadanandane C, Jambulingam P, Das PK. Anopheline fauna of Koraput District, Orissa state, with particular reference to transmission of malaria. Indian J Med Res. 1989;89:340-3.

[88] Mahapatra N, Marai NS, Ranjit MR, Parida SK, Hansdah DP, Hazra RK, Kar SK. Detection of Plasmodium falciparum infection in Anopheles mosquitoes from Keonjhar District, Orissa, India. J Vector Borne Dis. 2006;43(4):191-4.

[89] Prakash A, Bhattacharyya DR, Mohapatra PK, Mahanta J. Role of the prevalent Anopheles species in the transmission of Plasmodium falciparum and P. vivax in Assam state, north-eastern India. Ann Trop Med Parasitol. 2004;98(6):559-68.

[90] Ramasamy R, De Alwis R, Wijesundere A, Ramasamy MS. Malaria transmission at a new irrigation project in Sri Lanka: the emergence of Anopheles annularis as a major vector. Am J Trop Med Hyg. 1992;47(5):547-53.

[91] Rao TR. The anophelines of India, 2nd edition. New Delhi: Malaria Research Centre, Indian Council of Medical Research 1984.

[92] Garros C, Koekemoer LL, Coetzee M, Coosemans M, Manguin S. A single multiplex assay to identify major malaria vectors within the African Anopheles funestus and the Oriental An. minimus groups. Am J Trop Med Hyg. 2004 Jun;70(6):583-90.

[93] Walton C, Somboon P, O'Loughlin SM, Zhang S, Harbach RE, Linton YM, Chen B, Nolan K, Duong S, Fong MY, Vythilingum I, Mohammed ZD, Trung HD, Butlin RK. 
Genetic diversity and molecular identification of mosquito species in the Anopheles maculatus group using the ITS2 region of rDNA. Infect Genet Evol. 2007 Jan;7(1):93-102.

[94] Walton C, Handley JM, Kuvangkadilok C, Collins FH, Harbach RE, Baimai V, Butlin RK. Identification of five species of the Anopheles dirus complex from Thailand, using allele-specific polymerase chain reaction. Med Vet Entomol. 1999 Feb;13(1):24-32.

[95] Surendran SN, Abhayawardana TA, De Silva BG, Ramasamy R, Ramasamy MS. Anopheles culicifacies Y-chromosome dimorphism indicates sibling species (B and E) with different malaria vector potential in Sri Lanka. Med Vet Entomol. 2000;14(4): 437-40.

[96] Jude PJ, Dharshini S, Vinobaba M, Surendran SN, Ramasamy R. Anopheles culicifacies breeding in brackish waters in Sri Lanka and implications for malaria control. Malar J. 2010 Apr 21;9(1):106.

[97] Subbarao SK, Sharma VP. Anopheline species complexes and malaria control. Indian J Med Res. 1997;106:164-73.

[98] Amerasinghe PH, Amerasinghe FP, Konradsen F, Fonseka KT, Wirtz RA. Malaria vectors in a traditional dry zone village in Sri Lanka. Am J Trop Med Hyg. 1999;60(3): 421-9.

[99] Subbarao SK. The Anopheles culicifacies complex and control of malaria. Parasitol Today. 1988;4(3):72-5.

[100] Barik TK, Sahu B, Swain V. A review on Anopheles culicifacies: from bionomics to control with special reference to Indian subcontinent. Acta Trop. 2009 Feb;109(2):87-97.

[101] Sharma VP. Fighting malaria in India. Curr Sci. 1998;75:1127-40.

[102] Surendran SN, De Silva BG, Srikrishnaraj KA, Ramasamy MS, Ramasamy R. Establishment of species E, not B as the major vector of malaria in the Anopheles culicifacies complex in the country. Proc Sri Lanka Assoc Advmt Sci. 2003;59:18.

[103] Subbarao SK, Vasantha K, Raghavendra K, Sharma VP, Sharma GK. Anopheles culicifacies: siblings species composition and its relationship to malaria incidence. J Am Mosq Control Assoc. 1988;4(1):29-33.

[104] Vatandoost H, Shahi H, Abai MR, Hanafi-Bojd AA, Oshaghi MA, Zamani G. Larval habitats of main malaria vectors in Hormozgan Province and their susceptibility to different larvicides. Southeast Asian J Trop Med Public Health. 2004;35 Suppl 2:22-5.

[105] Surendran SN, Ramasamy R. Some characteristics of the larval breeding sites of Anopheles culicifacies species B and E in Sri Lanka. J Vector Borne Dis. 2005;42(2):39-44.

[106] Sabesan S, Krishnamoorthy K, Jambulingam P, Rajendran G, Kumar NP, Rajagopalan PK. Breeding habitats of Anopheles culicifacies in Rameswaram Island. Indian J Med Res. 1986;84:44-52. 
[107] Amerasinghe FP, Ariyasena TG. Larval survey of surface water-breeding mosquitoes during irrigation development in the Mahaweli Project, Sri Lanka. J Med Entomol. 1990;27(5):789-802.

[108] Roberts D. Mosquitoes (Diptera: Culicidae) breeding in brackish water: female ovipositional preferences or larval survival? J Med Entomol. 1996 Jul;33(4):525-30.

[109] Subbarao SK, Nanda N, Vasantha K, Dua VK, Malhotra MS, Yadav RS, Sharma VP. Cytogenetic evidence for three sibling species in Anopheles fluviatilis. Ann Entomol Soc Am. 1994;87:116-21.

[110] Chen B, Butlin RK, Pedro PM, Wang XZ, Harbach RE. Molecular variation, systematics and distribution of the Anopheles fluviatilis complex in southern Asia. Med Vet Entomol. 2006;20(1):33-43.

[111] Nandi J, Kaul SM, Sharma SN, Lal S. Anthropophily of anophelines in Duars of West Bengal and other regions of India. J Commun Dis. 2000;32(2):95-9.

[112] Nanda N, Yadav RS, Subbarao SK, Joshi H, Sharma VP. Studies on Anopheles fluviatilis and Anopheles culicifacies sibling species in relation to malaria in forested hilly and deforested riverine ecosystems in northern Orissa, India. J Am Mosq Control Assoc. 2000;16(3):199-205.

[113] Bhatt RM, Kohli VK. Biting rhythms of some anophelines in central Gujarat. Indian J Malariol. 1996;33(4):180-90.

[114] Malakar P, Das S, Saha GK, Dasgupta B, Hati AK. Indoor resting anophelines of north Bengal. Indian J Malariol. 1995;32(1):24-31.

[115] Nanda N, Joshi H, Subbarao SK, Yadav RS, Shukla RP, Dua VK, Sharma VP. Anopheles fluviatilis complex: host feeding patterns of species S, T, and U. J Am Mosq Control Assoc. 1996;12(1):147-9.

[116] Sharma SK, Nanda N, Dutta VK. Studies on the bionomics of Anopheles fluviatilis s.l. and the sibling species composition in the foothills of Shiwalik Range, India. Southeast Asian J Trop Med Public Health. 1995;26(3):566-72.

[117] Eshghi N, Motabar M, Javadian E, Manoutcheri AV. Biological features of Anopheles fluviatilis and its role in the transmission of malaria in Iran. Trop Geogr Med. 1976 Mar; 28(1):41-4.

[118] Naddaf SR, Oshaghi MA, Vatandoost H, Assmar M. Molecular characterization of Anopheles fluviatilis species complex in the Islamic Republic of Iran. East Mediterr Health J. 2003;9(3):257-65.

[119] Shukla RP, Pandey AC, Kohli VK, Ojha VP, Sharma VP. Bionomics of vector anophelines in District Naini Tal, Uttar Pradesh. Indian J Malariol. 1995;32(4):153-63.

[120] Shukla RP, Nanda N, Pandey AC, Kohli VK, Joshi H, Subbarao SK. Studies on bionomics of Anopheles fluviatilis and its sibling species in Nainital District, U.P. Indian J Malariol. 1998;35(2):41-7. 
[121] Reisen WK, Pradhan SP, Shrestha JP, Shrestha SL, Vaidya RG, Shrestha JD. Anopheline mosquito (Diptera: Culicidae) ecology in relation to malaria transmission in the inner and outer terai of Nepal, 1987-1989. J Med Entomol. 1993;30(4):664-82.

[122] Hanafi-Bojd AA, Vatandoost H, Jafari R. Susceptibility status of Anopheles dthali and An. fluviatilis to commonly used larvicides in an endemic focus of malaria, southern Iran. J Vector Borne Dis. 2006;43(1):34-8.

[123] Gunasekaran K. Age composition, natural survival and population growth of Anopheles fluviatilis James, 1902, the major malaria vector in the endemic belt of Koraput District, Orissa, India. Southeast Asian J Trop Med Public Health. 1994;25(1):196-200.

[124] Bhatt RM, Srivastava HC, Pujara PK. Biology of malaria vectors in central Gujarat. Indian J Malariol. 1994;31(2):65-76.

[125] Batra CP, Reuben R. Breeding of Anopheles stephensi (Liston) in wells and cisterns in Salem, Tamil Nadu. Indian J Med Res. 1979 Dec;70 Suppl:114-22.

[126] Batra CP, Mittal PK, Adak T, Subbarao SK. Efficacy of Agnique MMF monomolecular surface film against Anopheles stephensi breeding in urban habitats in India. J Am Mosq Control Assoc. 2006;22(3):426-32.

[127] Vatandoost H, Oshaghi MA, Abaie MR, Shahi M, Yaaghoobi F, Baghaii M, Hanafi-Bojd AA, Zamani G, Townson H. Bionomics of Anopheles stephensi Liston in the malarious area of Hormozgan Province, southern Iran, 2002. Acta Trop. 2006;97(2):196-203.

[128] Manouchehri AV, Javadian E, Eshighy N, Motabar M. Ecology of Anopheles stephensi Liston in southern Iran. Trop Geogr Med. 1976 Sep;28(3):228-32.

[129] Krishnan KS. A. stephensi Liston, 1901. Vectors of Malaria in India. 2nd ed. Delhi: National Society of India for Malaria and Other Mosquito-born Disease; 1961. p. 39-58.

[130] Zaim M, Ershadi MR, Manouchehri AV, Hamdi MR. The use of CDC light traps and other procedures for sampling malaria vectors in southern Iran. J Am Mosq Control Assoc. 1986;2(4):511-5.

[131] Reisen WK. Population dynamics of some Pakistan mosquitoes: the impact of residual organophosphate insecticide spray on anopheline relative abundance. Ann Trop Med Parasitol. 1986;80(1):69-75.

[132] Sweet WC, Rao B. Races of Anopheles stephensi Liston, 1901. Ind Med Gaz. 1937;72:665-74.

[133] Singh OP. Bionomics of malaria vectors in India: Malaria Research Centre 2002.

[134] Cox-Singh J, Singh B. Knowlesi malaria: newly emergent and of public health importance? Trends Parasitol. 2008 Sep;24(9):406-10.

[135] Vythilingam I. Plasmodium knowlesi and Wuchereria bancrofti: their vectors and challenges for the future. Front Syst Biol. 2012;3(115). 
[136] Rosenberg R, Andre RG, Somchit L. Highly efficient dry season transmission of malaria in Thailand. Trans R Soc Trop Med Hyg. 1990;84(1):22-8.

[137] Manguin S, Garros C, Dusfour I, Harbach RE, Coosemans M. Bionomics, taxonomy, and distribution of the major malaria vector taxa of Anopheles subgenus Cellia in Southeast Asia: An updated review. Infect Genet Evol. 2008 Nov 29;8:489-503.

[138] Peyton EL, Harrison BA. Anopheles (Cellia) dirus, a new species of the Leucosphyrus Group from Thailand (Diptera: Culicidae). Mosq Syst. 1979;11(1):40-52.

[139] Peyton EL, Harrison BA. Anopheles (Cellia) takasagoensis Morishita 1946, an additional species in the Balabacensis Complex of Southeast Asia (Diptera: Culicidae). Mosq Syst. 1980;12(3):335-47.

[140] Peyton EL, Ramalingam S. Anopheles (Cellia) nemophilous, a new species of the Leucosphyrus Group from peninsular Malaysia and Thailand (Diptera: Culicidae). Mosq Syst. 1988;20:272-99.

[141] Sallum MA, Peyton EL, Wilkerson RC. Six new species of the Anopheles leucosphyrus group, reinterpretation of An. elegans and vector implications. Med Vet Entomol. 2005;19(2):158-99.

[142] Takano KT, Nguyen NT, Nguyen BT, Sunahara T, Yasunami M, Nguyen MD, Takagi M. Partial mitochondrial DNA sequences suggest the existence of a cryptic species within the Leucosphyrus group of the genus Anopheles (Diptera: Culicidae), forest malaria vectors, in northern Vietnam. Parasit Vectors. 2010;3:41.

[143] Dutta P, Bhattacharyya DR, Khan SA, Sharma CK, Mahanta J. Feeding patterns of Anopheles dirus, the major vector of forest malaria in north east India. Southeast Asian J Trop Med Public Health. 1996;27(2):378-81.

[144] Manguin S, Bangs MJ, Pothikasikorn J, Chareonviriyaphap T. Review on global cotransmission of human Plasmodium species and Wuchereria bancrofti by Anopheles mosquitoes. Infect Genet Evol. 2010 Mar;10(2):159-77.

[145] Prakash A, Bhattacharyya DR, Mohapatra PK, Mahanta J. Malaria transmission risk by the mosquito Anopheles baimaii (formerly known as An. dirus species D) at different hours of the night in North-east India. Med Vet Entomol. 2005;19(4):423-7.

[146] Rattanarithikul R, Konishi E, Linthicum KJ. Detection of Plasmodium vivax and Plasmodium falciparum circumsporozoite antigen in anopheline mosquitoes collected in southern Thailand. Am J Trop Med Hyg. 1996;54(2):114-21.

[147] Vythilingam I, Phetsouvanh R, Keokenchanh K, Yengmala V, Vanisaveth V, Phompida S, Hakim SL. The prevalence of Anopheles (Diptera: Culicidae) mosquitoes in Sekong Province, Lao PDR in relation to malaria transmission. Trop Med Int Health. 2003;8(6): 525-35. 
[148] Trung HD, Bortel WV, Sochantha T, Keokenchanh K, Briet OJ, Coosemans M. Behavioural heterogeneity of Anopheles species in ecologically different localities in Southeast Asia: a challenge for vector control. Trop Med Int Health. 2005;10(3):251-62.

[149] Misra SP, Nandi J, Narasimham MV, Rajagopal R. Malaria transmission in Nagaland, India. Part I. Anophelines and their seasonality. J Commun Dis. 1993;25(2):62-6.

[150] Baimai V. Population cytogenetics of the malaria vector Anopheles leucosphyrus group. Southeast Asian J Trop Med Public Health. 1988;19(4):667-80.

[151] Prakash A, Bhattacharyya DR, Mohapatra PK, Mahanta J. Physico-chemical characteristics of breeding habitats of Anopheles dirus (Diptera: Culicidae) in Assam, India. J Environ Biol. 2002 Jan;23(1):95-100.

[152] Prakash A, Bhattacharyya DR, Mohapatra PK, Mahanta J. Breeding and day resting habitats of Anopheles dirus in Assam, India. Southeast Asian J Trop Med Public Health. 1997;28(3):610-4.

[153] Oo TT, Storch V, Becker N. Studies on the bionomics of Anopheles dirus (Culicidae: Diptera) in Mudon, Mon State, Myanmar. J Vector Ecol. 2002;27(1):44-54.

[154] Htay A, Minn S, Thaung S, Mya MM, Than SM, Hlaing T, Soe S, Druilhe P, Queuche F. Well-breeding Anopheles dirus and their role in malaria transmission in Myanmar. Southeast Asian J Trop Med Public Health. 1999;30(3):447-53.

[155] Harbach RE, Garros C, Manh ND, Manguin S. Formal taxonomy of species C of the Anopheles minimus sibling species complex (Diptera: Culicidae). Zootaxa. 2007;1654:41-54.

[156] Harbach RE, Parkin E, Chen B, Butlin RK. Anopheles (Cellia) minimus Theobald (Diptera: Culicidae): neotype designation, characterization, and systematics. Proc Entomol Soc Wash. 2006;108(1):198-209.

[157] Somboon P, Rory A, Tsuda Y, Takagi M, Harbach RE. Systematics of Anopheles (Cellia) yaeyamaensis sp. n., alias species $\mathrm{E}$ of the An. minimus complex of southeastern Asia (Diptera: Culicidae). Zootaxa. 2010;2651:43-51.

[158] Farid MA, Chen CT, Hsu TC, Liu SY. Report of WHO evaluation team on malaria eradication in the Ryukyu Islands, 1965. Geneva1966.

[159] Miyagi I, Toma T, Malenganisho WL, Uza M. Historical review of mosquito control as a component of malaria eradication program in the Ryukyu Archipelago. Southeast Asian J Trop Med Public Health. 1996;27(3):498-511.

[160] Garros C, Van Bortel W, Trung HD, Coosemans M, Manguin S. Review of the Minimus Complex of Anopheles, main malaria vector in Southeast Asia: from taxonomic issues to vector control strategies. Trop Med Int Health. 2006 Jan;11(1):102-14.

[161] Rongnoparut P, Ugsang DM, Baimai V, Honda K, Sithiprasasna R. Use of a remote sensing-based geographic information system in the characterizing spatial patterns for 
Anopheles minimus A and C breeding habitats in western Thailand. Southeast Asian J Trop Med Public Health. 2005 Sep;36(5):1145-52.

[162] Rattanarithikul R, Green CA, Panyim S, Noigamol C, Chanaimongkol S, Mahapibul P. Larval habitats of malaria vectors and other Anopheles mosquitoes around a transmission focus in northwestern Thailand. J Am Mosq Control Assoc. 1995;11(4):428-33.

[163] Khan SA, Handique R, Tewari SC, Dutta P, Narain K, Mahanta J. Larval ecology and mosquito fauna of upper Brahmaputra valley, northeast India. Indian J Malariol. 1998;35(3):131-45.

[164] Harrison BA. Medical entomology studies - XIII. The Myzomyia Series of Anopheles (Cellia) in Thailand, with emphasis on intra-interspecific variations (Diptera: Culicidae). Contrib Am Entomol Inst (Ann Arbor). 1980;17:1-195.

[165] Dev V. Anopheles minimus: its bionomics and role in the transmission of malaria in Assam, India. Bull World Health Organ. 1996;74(1):61-6.

[166] Van Bortel W, Trung HD, Manh ND, Roelants P, Verle P, Coosemans M. Identification of two species within the Anopheles minimus complex in northern Vietnam and their behavioural divergences. Trop Med Int Health. 1999;4(4):257-65.

[167] Dev V, Bhattacharyya PC, Talukdar Rupjyoti. Transmission of malaria and its control in the northeastern region of India. J Assoc Physicians India. 2003;51:1073-6.

[168] Chareonviriyaphap T, Prabaripai A, Bangs MJ, Aum-Aung B. Seasonal abundance and blood feeding activity of Anopheles minimus Theobald (Diptera: Culicidae) in Thailand. J Med Entomol. 2003;40(6):876-81.

[169] Suthas N, Phorn S, Udom C, Cullen JE. The behaviour of Anopheles minimus Theobald (Diptera: Culicidae) subjected to different levels of DDT selection pressure in northern Thailand. Bull Entomol Res. 1986;76:303-12.

[170] Ismail IA, Notananda V, Schepens J. Studies on malaria and responses of Anopheles balabacensis balabacensis and Anopheles minimus to DDT residual spraying in Thailand. I. Pre-spraying observations. Acta Trop. 1974;31(2):129-64.

[171] Garros C, Marchand RP, Quang NT, Hai NS, Manguin S. First record of Anopheles minimus $\mathrm{C}$ and significant decrease of An. minimus A in central Vietnam. J Am Mosq Control Assoc. 2005 Jun;21(2):139-43.

[172] Van Bortel W, Trung HD, Sochantha T, Keokenchan K, Roelants P, Backeljau T, Coosemans M. Eco-ethological heterogeneity of the members of the Anopheles minimus complex (Diptera: Culicidae) in Southeast Asia and its consequences for vector control. J Med Entomol. 2004 May;41(3):366-74.

[173] Sungvornyothin S, Muenvorn V, Garros C, Manguin S, Prabaripai A, Bangs MJ, Chareonvirlyaphap T. Trophic behavior and biting activity of the two sibling species of the Anopheles minimus complex in western Thailand. J Vector Ecol. 2006 Dec;31(2): 252-61. 
[174] Cooper RD, Waterson DG, Frances SP, Beebe NW, Sweeney AW. Speciation and distribution of the members of the Anopheles punctulatus (Diptera: Culicidae) group in Papua New Guinea. J Med Entomol. 2002;39(1):16-27.

[175] Cooper RD, Waterson DG, Frances SP, Beebe NW, Pluess B, Sweeney AW. Malaria vectors of Papua New Guinea. Int J Parasitol. 2009 Jun 5;39(13):1495-501.

[176] Bugoro H, Cooper RD, Butafa C, Iro'ofa C, Mackenzie DO, Chen CC, Russell TL. Bionomics of the malaria vector Anopheles farauti in Temotu Province, Solomon Islands: issues for malaria elimination. Malar J. 2011;10:133.

[177] Ebsworth P, Bryan JH, Foley DH. Ecological distribution of mosquito larvae of the Anopheles punctulatus group on Niolam (Lihir) Island, Papua New Guinea. J Am Mosq Control Assoc. 2001;17(3):181-5.

[178] Cooper RD, Frances SP. Malaria vectors on Buka and Bougainville Islands, Papua New Guinea. J Am Mosq Control Assoc. 2002;18(2):100-6.

[179] Beebe NW, Bakote'e B, Ellis JT, Cooper RD. Differential ecology of Anopheles punctulatus and three members of the Anopheles farauti complex of mosquitoes on Guadalcanal, Solomon Islands, identified by PCR-RFLP analysis. Med Vet Entomol. 2000;14(3): 308-12.

[180] Charlwood JD, Graves PM, Alpers MP. The ecology of the Anopheles punctulatus group of mosquitoes from Papua New Guinea: a review of recent work. P N G Med J. 1986;29(1):19-26.

[181] Charlwood JD. The influence of larval habitat on the ecology and behavior of females of the Punctulatus Group of Anopheles mosquitoes from Papua New Guinea. In: Lounibos LP, Rey JR, Frank JH, editors. Ecology of mosquitoes: Proceedings of a workshop. Vero Beach: Florida Medical Entomology Laboratory; 1985. p. 399-406.

[182] Beebe NW, Cooper RD, Morrison DA, Ellis JT. A phylogenetic study of the Anopheles punctulatus group of malaria vectors comparing rDNA sequence alignments derived from the mitochondrial and nuclear small ribosomal subunits. Mol Phylogenet Evol. 2000 Dec;17(3):430-6.

[183] Lee DJ, Hicks MM, Griffiths M, Debenham ML, Bryan JH, Russell RC, Geary M, Marks EN. The Culicidae of the Australasian Region. Volume 5. Nomenclature, synonymy, literature, distribution, biology and relation to disease. Genus Anopheles. Subgenera Anopheles, Cellia. Canberra: Australian Government Publishing Service; 1987.

[184] Charlwood JD. A differential response to mosquito nets by Anopheles and Culex mosquitoes from Papua New Guinea. Trans R Soc Trop Med Hyg. 1986;80(6):958-60.

[185] Spenser T, Spenser M, Venters D. Malaria vectors of Papua New Guinea. P N G Med J. 1974;17(1):22-30. 
[186] Bangs MJ, Subianto DB. El Nińo and associated outbreaks of severe malaria in highland populations in Irian Jaya, Indonesia: a review and epidemiological perspective. Southeast Asian J Trop Med Public Health. 1999 Dec;30(4):608-19.

[187] De'ath G. Boosted trees for ecological modeling and prediction. Ecology. 2007 Jan;88(1): 243-51.

[188] Elith J, Leathwick JR, Hastie T. A working guide to boosted regression trees. J Anim Ecol. 2008 Jul;77(4):802-13. 
